\title{
O TRIUNFO DA MORTE (c. 1562) DE BRUEGEL, $O$ VELHO (c. 1525-1569) \\ UMA LEITURA SONORA DO MACABRO ESPETÁCULO ARTÍSTICO
}

\section{The Triumph of Death (c. 1562) by Bruegel the Elder (c. 1525- 1569) \\ A sound reading of the macabre artistic spectacle}

\author{
Prof. Dr. Ricardo da Costa \\ Acadèmic corresponent a l'estranger $\mathrm{n} .59 \mathrm{da}$ \\ Reial Acadèmia de Bones Lletres de Barcelona \\ Prof. Titular da Universidade Federal do Espírito Santo (UFES) \\ ORCID: https://orcid.org/0000-0002-1817-9091 \\ Email: ricardo@ricardocosta.com
}

Resumo: Análise dos temas macabros expostos na famosa pintura $O$ Triunfo da Morte (c. 1562) de Bruegel, o Velho (c. 1525-1569). Minha proposta interpretativa é a de apreciar as imagens a partir das sugestões musicais que o artista representa, e que a densidade do drama da existência diante da morte nessa obra de Bruegel pode ser compreendida de forma mais aprofundada com a confrontação das imagens do quadro com a musicalidade dos instrumentos e sonoridade das cenas.

Palavras-chave: História da Arte - Bruegel, o Velho - Morte.

Abstract: Analysis of the macabre themes exposed in the famous painting The Triumph of Death (c. 1562), by Bruegel the Elder (c. 1525-1569). My interpretive proposal is to appreciate the images from the musical suggestions that the artist represents, and that the density of the drama of existence in the face of death can be understood more profoundly with the confrontation of the painting's images with the musicality of the instruments and the sound of scenes.

Keywords: History of Art - Bruegel the Elder - Death.

Résumé: Analyse des thèmes macabres exposés dans le célèbre tableau Le Triomphe de la Mort (vers 1562) de Bruegel l'Ancien (vers 1525-1569). Ma proposition interprétative est d'apprécier les images à partir des suggestions musicales que l'artiste représente, et que la densité du drame de l'existence face à la mort dans cette œuvre de Bruegel puisse être appréhendée plus en profondeur avec la confrontation des images du tableau avec la musicalité des instruments et la sonorité des scènes.

Mots-clés: Histoire de l'art - Bruegel l'Ancien - Mort. 
IMAGEM 1 - $O$ TRIUNFO DA MORTE (C. 1562) DE BRUEGEL, $O$ VELHO (15251569). ÓLEO SOBRE MADEIRA, 117 X 162 CM, MUSEO DEL PRADO, SALA 025.

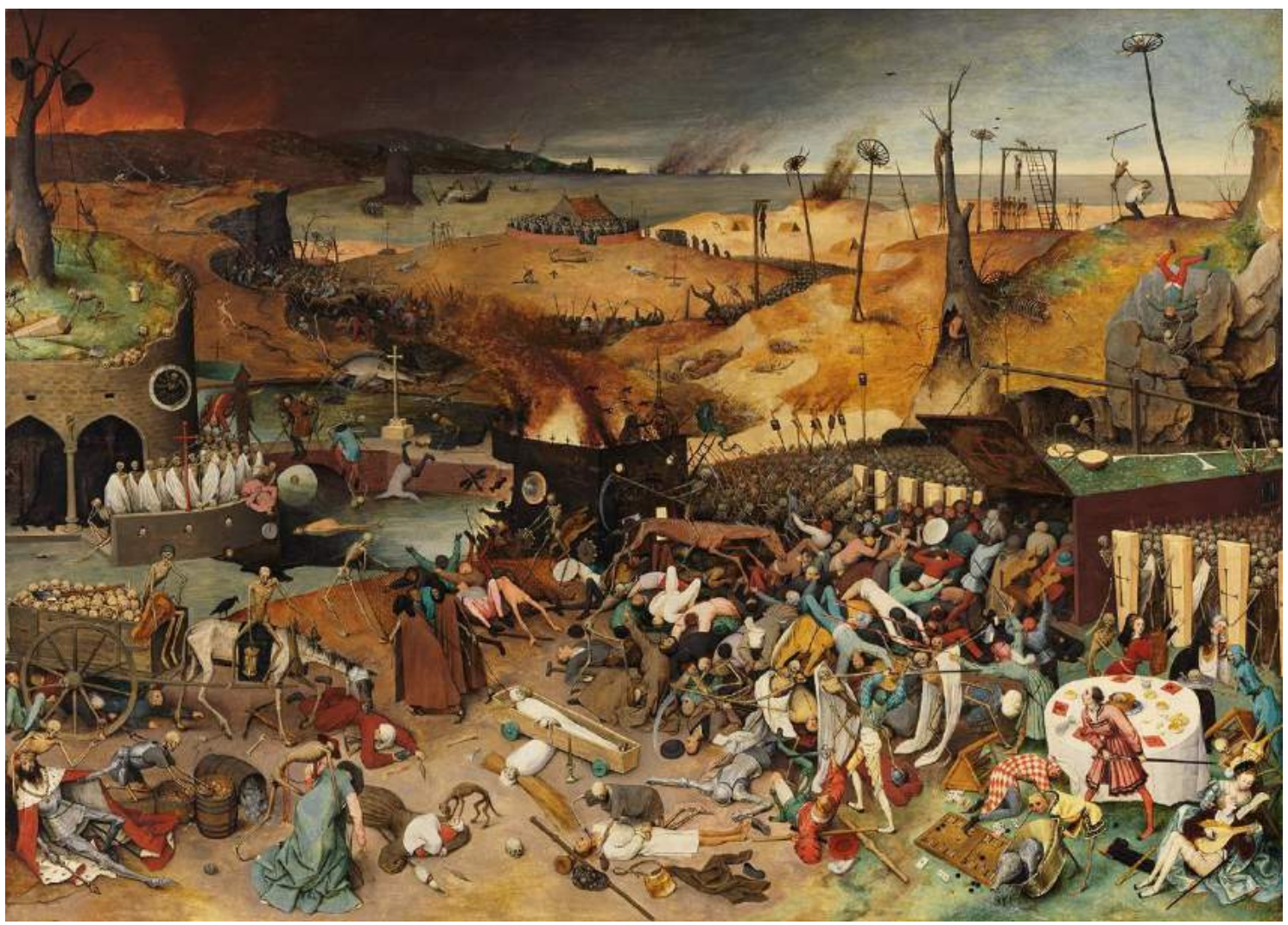

Multiplicastes vossos mortos nesta cidade e enchestes vossas ruas de mortos. Ez 11, 6.

\section{Ezequiel, inspiração bíblica?}

O panorama é de desolação. Horror. Um espetáculo mórbido, um mundo sem esperança, sem Deus, de um antropomorfismo selvagem, virulentamente hostil. ${ }^{1}$ Talvez a melhor alusão bíblica à imagem criada pelo artista seja a do profeta Ezequiel (séc. VI a. C.) - aliás, também reverenciado no Islamismo e na fé (persa) Bahá'í (بهائى). As visões simbólicas do profeta, admoestadoras da destruição de Jerusalém e recebidas durante o exílio babilonico (c. 586-538 a. C.), são as primeiras que me vêm à mente para alegorizar biblicamente a fúnebre e devastadora paisagem do Triunfo da Morte (c. 1562) do pintor Pieter Bruegel, o Velho (c. 1525-1569) (imagem 1). Em qualquer tema artístico da tradição ocidental medieval, cristã, é fundamental procurar suas bases bíblicas, como bem sabem os (melhores) medievalistas - especialmente para seu pensamento analógico, fonte de suas imagens mentais. ${ }^{3}$ 


\section{O método}

São muitas as cenas do quadro. Bruegel é pintor de múltiplos acontecimentos simultâneos, de tempos paralelos e entrecruzados, de múltiplas e variegadas sonoridades. E de dezenas de personagens. Por isso, baseado em método visual de Carlo Ginzburg (1939-) ${ }^{4}$, para abordar as várias cenas macabras do quadro, dividi a imagem em duas partes transversais (esquema 1), além de me valer da proposta metodológica de José Enrique Ruiz-Domènec (1948-) - compreender os registros do Passado em seu contexto musical ${ }^{5}$ - ideia já desenvolvida por Roger Scruton (1944-2020) ${ }^{6}$, e aplicá-la nesse estudo.

Primeiro, as imagens. Depois, com elas, em contraponto a elas, os sons aludidos. Em sua dignidade estético-afetiva ${ }^{7}$, as sonoridades matizam as cenas, estilizam as alusões, ornamentam os pavorosos assombros das ironias fúnebres do quadro. ${ }^{8}$ As duas partes da paisagem macabra parecem sinuosamente irradiar-se de baixo para cima, a partir do olhar estupefato, atônito, do boquiaberto cavaleiro (na parte inferior, à direita) em direção ao seu oposto - parte superior, à esquerda do observador - em que, no alto de um telhado gramado de uma torre, dois esqueletos soam imensos sinos fúnebres postos no cume de uma árvore seca, morta, a anunciar o final dos tempos, como trombetas do Apocalipse, enquanto duas outras caveiras desenterram um esquife (imagem 2).

\section{Esquema 1}

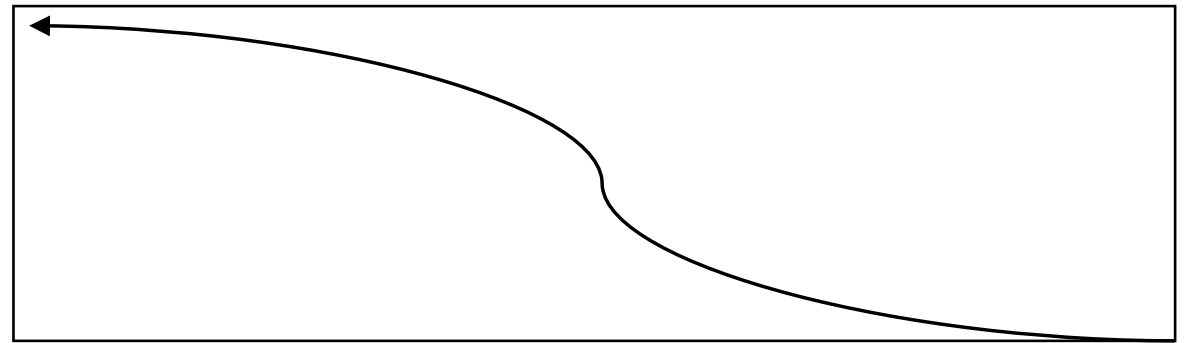




\section{Imagem 2}

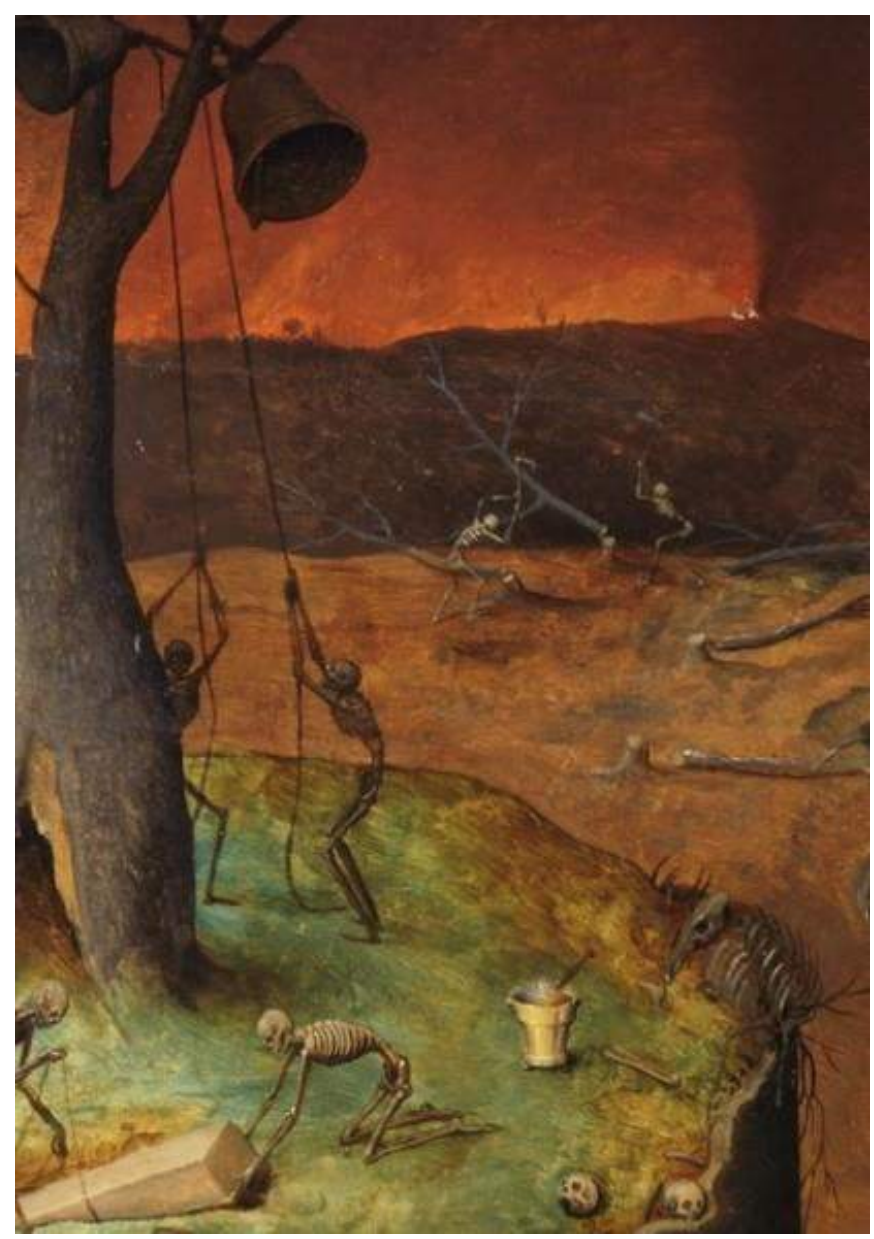

As badaladas da morte proporcionam uma das sonoridades imaginárias do quadro - a pintura faz alusões à Música e a ambientes sonoros, como veremos (como contraponto aos gemidos e gritos que destaca). Ao fundo, numa paisagem incendiária, duas caveiras em júbilo cortam troncos de árvores mortas - imaginem o som da madeira ressecada sendo cortada por machados. Nada pode sobreviver. 


\section{A quixotesca defesa do Amor}

No canto direito inferior, oposto às badaladas (imagem 3), como dito, um desgrenhado e assustado cavaleiro desembainha sua espada. Bruegel parece querer que fixemos nosso olhar nele. Sua fisionomia, horrorizada, representa a consciência que terá uma mors repentina, morte ignominiosa, porque não terá o benefício do Viático comunhão eucarística dada aos que estão prestes a morrer. ${ }^{9}$

Com esse gesto algo quixotesco, parece tentar (inutilmente) defender o enamorado casal que parece não se importar com seu fim.

\section{Imagem 3}

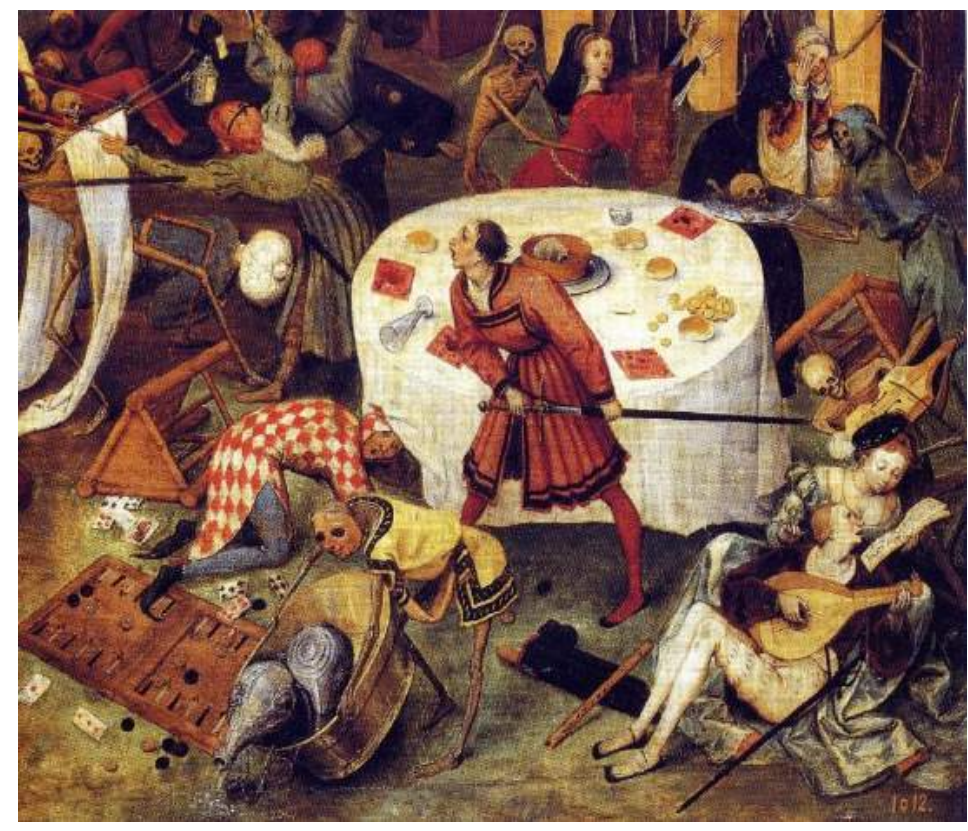

De fato, além de dividir transversalmente a paisagem em duas partes, todas as outras cenas parecem ter sua origem a partir desse minúsculo porém significativo (e pecaminoso) espaço. O apaixonado casal-cortesão sorve, entretido, essas que serão as últimas notas da melodia de seu amor cortês, não sem a soturna presença de um músicoesqueleto acima de suas cabeças, que toca uma rabeca, instrumento costumeiramente usado em celebrações (e artisticamente muito representado com anjos músicos ${ }^{10}$ ), fina ironia do pintor. ${ }^{11}$ 
O trovador, sentado sobre o vestido de sua dama, dedilha um alaúde, enquanto ela segura suave e docemente a partitura para que seu amado leia a canção. A seus pés, uma flauta e uma sacola de veludo que guarda outras flautas - era comum na época o instrumentista carregar flautas de vários tamanhos (cada uma numa afinação específica) para acompanhar os diferentes instrumentos. ${ }^{12}$ Como a tessitura dos instrumentos era limitada, era raro tocar com uma única flauta e ser acompanhado por instrumentos de distintas afinações (ou mesmo cantores de diferentes timbres- soprano, contralto, tenor, baixo). ${ }^{13}$

Essa é a única cena do Triunfo da Morte em que há uma ode à vida. Por estar numa paisagem apocalíptica, soa melancólica - a expressão triste do trovador manifesta esse estado anímico síntese do séc. XVI, tão marcante que, apenas algumas décadas após a feitura do quadro, em 1621, o clérigo e professor de Oxford, Robert Burton (1577-1640), publicou A anatomia da melancolia. ${ }^{14}$ A poetisa confessional norteamericana Sylvia Plath $(1932-1963)^{15}$ dedicou versos em homenagem ao casal bruegeliano $^{16}$ :

In Brueghel's panorama of smoke and slaughter

Two people only are blind to the carrion army:

$\mathrm{He}$, afloat in the sea of her blue satin

Skirts, sings in the Direction

Of her bare shoulder, while she bends,

Finger a leaflet of music, over him,

Both of them deaf to the fiddle in the hands

Of the death's-head shadowing their song.

These Flemish lovers flourish; not for long.

Yet desolation, stalled in paint, spares the little country

Foolish, delicate, in the lower right hand corner. ${ }^{17}$

No sombrio panorama do massacre de Bruegel apenas dois são cegos ao exército da podridão:

ele, a flutuar no mar de cetim azul

da saia dela, canta na direção

de seu colo descoberto, que se inclina, com um dedo na partitura, sobre ele.

Ambos estão surdos ao violino nas mãos da cabeça da morte que sombreia sua canção.

Esses amantes flamencos florescem, mas não por muito tempo.

Todavia, a desolação, assentada na pintura, poupa o pequeno espaço

tolo, delicado, no canto inferior direito (trad.: Ricardo da Costa). 
Ao redor da mesa de linho branco (que, além de pães e uma taça, tem um crânio ao centro), vários instantes de pavor: acima, à esquerda, dois cortesãos fogem; ao centro, uma dama é segura pela cintura por esqueleto que parece sorrir, e sua aia coloca as mãos no rosto; à direita, uma caveira, com vestes azuis, derruba uma cadeira e serve um crânio num prato, também azul.

Abaixo da mesa, além do casal de enamorados, uma caveira com uma túnica amarela e uma máscara sorridente derrama bebida de dois grandes jarros. Assustado, o bobo da corte, figura da alegria cortesã juntamente com o trovador, corre para se esconder embaixo da mesa: sua função bufa, livre do medo da censura, esvaziou-se com o pavor da morte. As cartas foram lançadas ao chão, juntamente com o jogo de gamão.

$O$ Triunfo da Morte foi redescoberto no séc. XX. Além da poetisa Sylvia Plath, o escritor pós-moderno Don DeLillo (1936-) percebeu, na imediatez do quadro, o caráter desses únicos protagonistas de uma cena social: todos são pecadores (jogadores, amantes... ${ }^{18}$ ). Por isso, a morte esvazia os odres cheios de bebida (provavelmente vinho, ainda que o pintor não tenha destacado a cor rubi do líquido caindo no chão).

\section{Esquema 2}

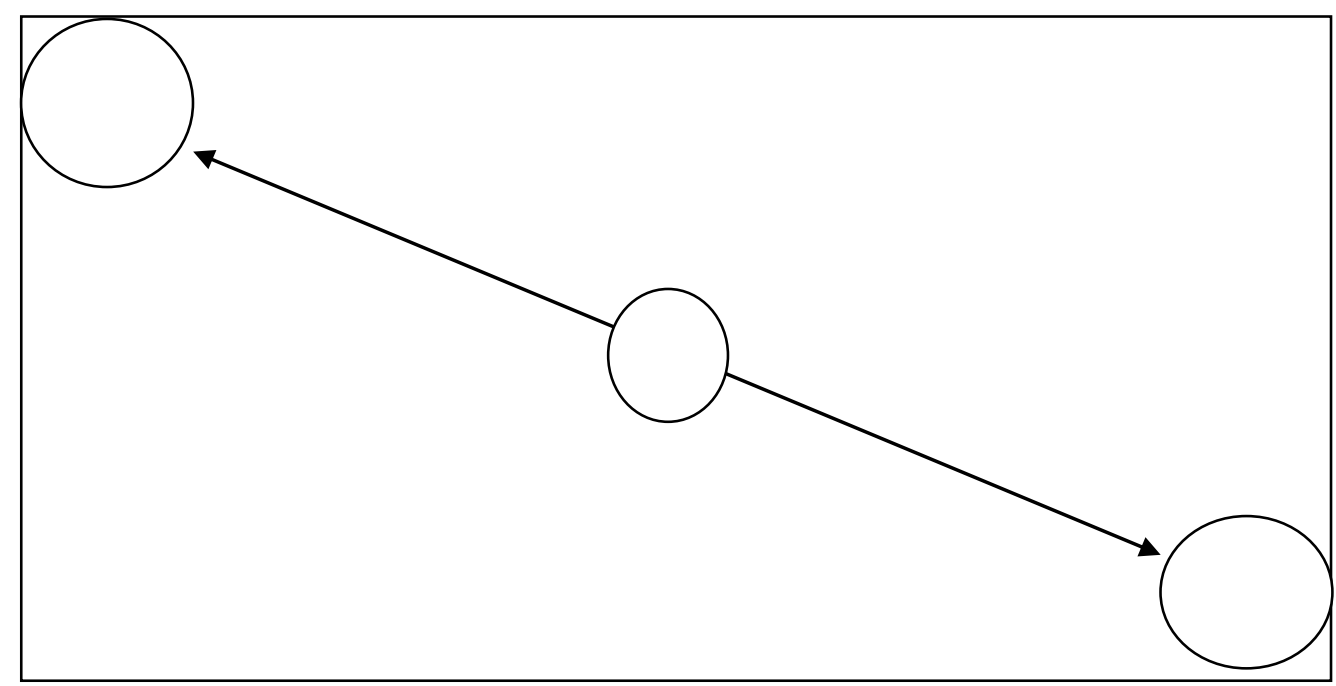


Como disse, essa cena no canto inferior direito do quadro redimensiona e divide toda a paisagem em um sentido diagonal. A sensação do recorte dessa geografia é reforçada pelas falésias na metade superior da cena e acrescida pelas labaredas ao centro, chamas posicionadas atrás de uma muralha de metal enferrujado com um portão em forma de boca e uma sombra de sentinela, que também guarda uma soturna gaiola pontiaguda com dois pássaros negros - e insufla uma fina trombeta nas costas da Morte, que cavalga um esquálido cavalo, quase ao centro do quadro (imagem 4).

\section{Imagem 4}

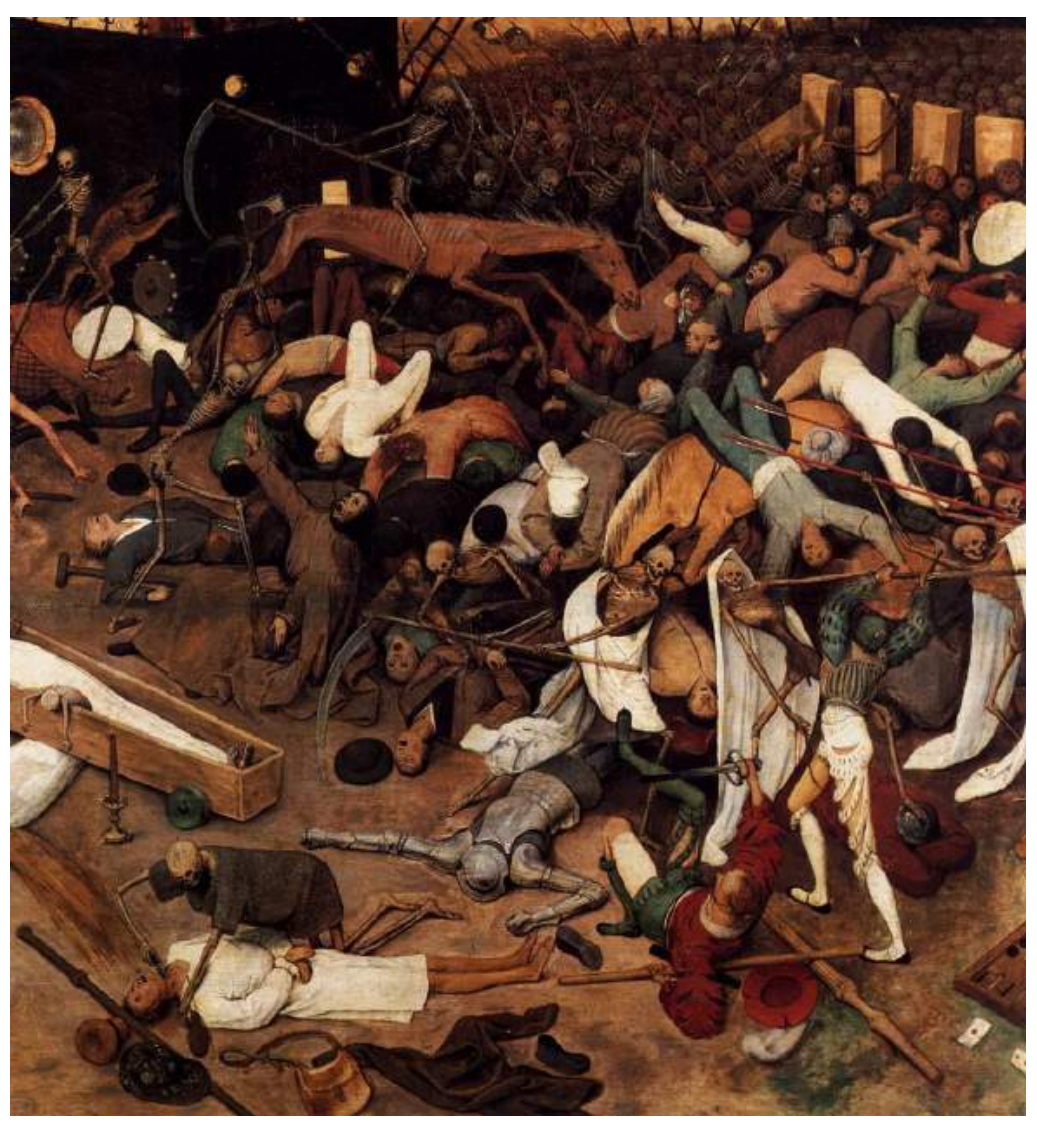

A Morte lidera um exército de esqueletos. Cavalga um esquálido, mas impetuoso cavalo amarelo-rubro-esverdeado (indício da decomposição da morte) e porta uma enorme foice com a qual ceifa a vida de dezenas de pessoas à sua frente. ${ }^{19}$ Para que sua devastação seja completa, o quarto cavaleiro do Apocalipse é auxiliado por capitãesesqueletos com véus brancos que, com longas foices, pressionam e dilaceram a triste 
multidão. Homens, mulheres (uma, com os braços erguidos, nua), todos se comprimem e pisoteiam uns aos outros. À esquerda, logo abaixo da Morte a cavalo, um esqueletolugar-tenente (sem o véu branco) alça seu machado, prestes a cortar a cabeça de uma senhora de véu negro, que implora por sua vida. Parece uma carmelita, por seu hábito castanho - nem a ordem mendicante mais humilde escapa ao holocausto. ${ }^{20}$

Dois cavaleiros (à direita, abaixo) esgrimam inutilmente contra dois esqueletos. Um, de vermelho, já caiu, embora ainda lute, desesperadamente. ${ }^{21} \mathrm{~A}$ seu lado, à esquerda, uma caveira corta o pescoço de um peregrino, de túnica branca, no chão. Não é um peregrino de boa cepa: tem uma bolsa de moedas presa ao pescoço. Por isso - e por ser um penitente, sou tentado a especular que seja uma alusão aos judeus que, por não poderem legalmente exercer qualquer profissão, eram costumeiramente agiotas. ${ }^{22}$ Cena impiedosa: morreu sem poder honrar sua dívida? Seja como for, também pode ser uma crítica à venda de indulgências, como Lutero em suas 95 teses. $^{23}$

Os atributos do peregrino jazem ao seu lado - o cajado, estirado acima de sua cabeça, o chapéu (bordado com cruzes e outros símbolos) e a cabaça do peregrino (para transportar água). Sua bolsa de peregrino (fechada, não aberta, como de hábito, para representar sua humildade) está à sua direita, com seu manto e sapatos. Talvez pensasse que escaparia do horror da morte. Não, nem os romeiros são poupados.

\section{Imagem 5}

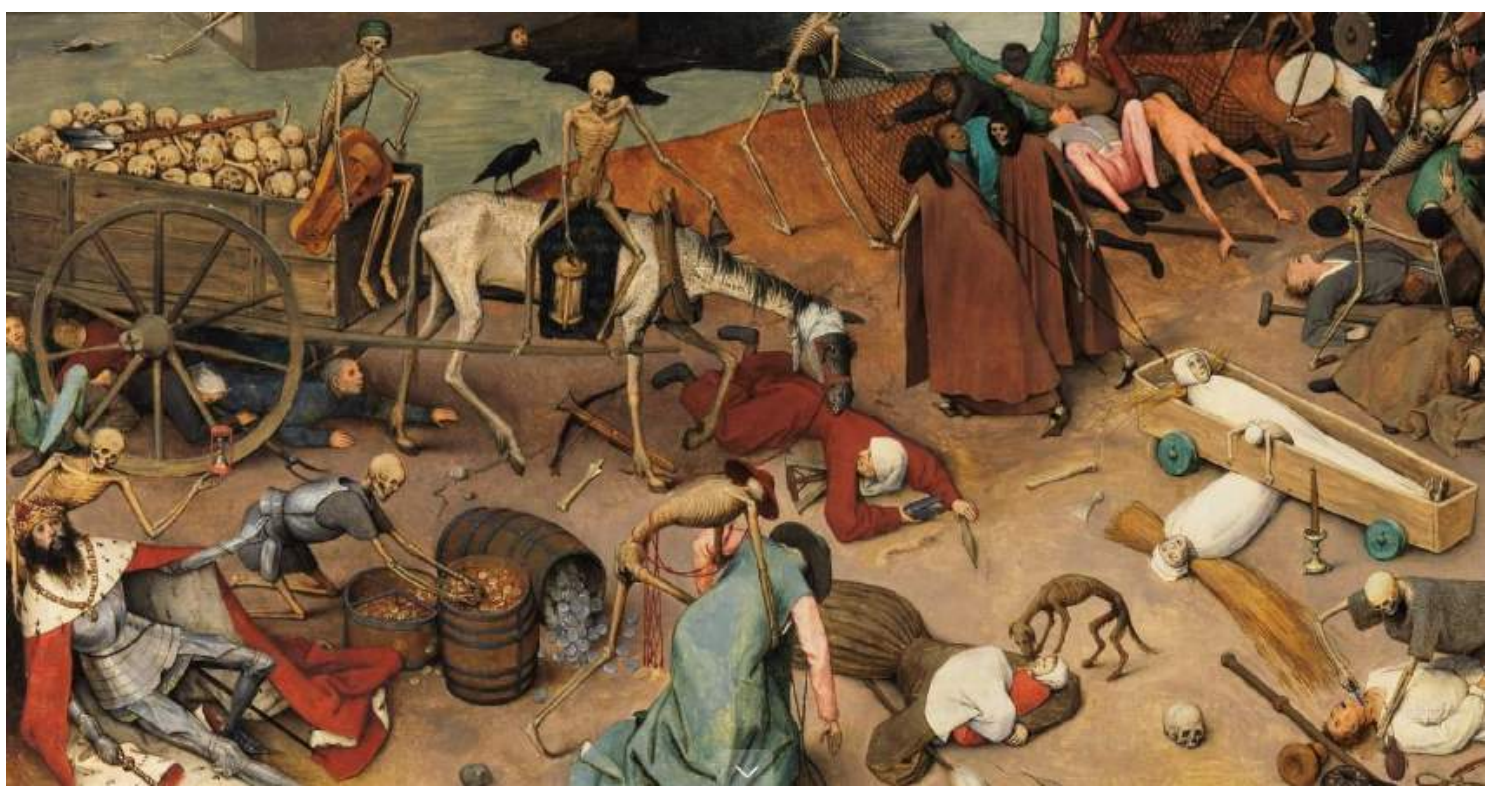


A tônica das expressões faciais é de horror. Mais que qualquer outro artista de seu tempo, Bruegel expressa nos rostos as forças que atuam neles: são instrumentos do dizer. ${ }^{24}$ Bocas abertas, perplexas, atônitas diante da velocidade e da impiedade do massacre.

No canto inferior à esquerda do espectador, uma amarelada caveira com uma ampulheta na mão esquerda escora um desfalecido rei e aguarda sua morte. Ainda que esteja zombeteiramente sorrindo (nem os governantes escapam do destino), ela demonstra respeito: é um monarca, merece a última dignidade da espera. Por isso ela acompanha seus derradeiros instantes.

Coroado, com armadura completa e manto púrpura com moqueta (esmalte heráldico que representa a pele de arminho - alusão ao brasão dos duques da Bretanha), cetro dourado e espada, mesmo em seus últimos momentos o imperador ainda demonstra preocupação com sua riqueza: com os olhos esbugalhados, ele estende a mão esquerda para outra caveira, armada, provavelmente símbolo de um vassalo, que saqueia seus barris cheios de moedas de ouro e de prata. ${ }^{25}$ Imagine-se o som da morte monárquica: o espraiado e inarmônico comportamento acústico do tilintar de suas moedas, dinheiro que não poderá levar para o Além. ${ }^{26}$ Como diz o salmista, “...quando morrer, nada levará consigo, nem a sua glória o acompanhará” $(\mathrm{S} 149,17) .{ }^{27}$

Alguns passos à frente do atônito monarca, um bispo é amparado por uma caveira-cardeal (com seu galero vermelho com borlas). Bruegel é algo respeitoso com a Igreja: a caveira-cardeal ampara delicada e suavemente o corpo do religioso. Respeito, porém não sem algum sarcasmo interna corporis - a mão que afaga é a mesma que apedreja... ${ }^{28}$ De qualquer modo, ambos, rei e bispo, representam o poder secular e o poder espiritual ${ }^{29}$ : ambos serão ceifados. A morte não poupa ninguém. ${ }^{30}$

Acima do rei e do bispo, uma impressionante carroça cheia de crânios é conduzida por um esqueleto montado em um esquálido cavalo. Ele tem uma sineta na mão 
esquerda e um candeeiro na direita para anunciar sua chegada. ${ }^{31} \mathrm{Um}$ sinistro corvo pousou no lombo do animal. Dessa carroça até um macilento cachorro que cheira uma criança no chão ao lado de sua mãe morta, abraçada a uma roca, com um fuso ao lado

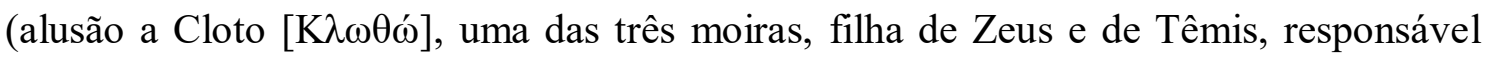
por tecer os fios das vidas dos homens; mesmo essa filha da Necessidade ${ }^{32}$ morreu), Bruegel "fecha" a cena com um longo arco imaginário.

Sigamos essa linha. Na carroça, acima dos crânios, há uma pá: ela indica que os esqueletos passam para recolher os ossos (inclusive sobre pessoas ainda vivas - uma delas embaixo da carroça é um besteiro, que tenta inutilmente alcançar sua besta). $\mathrm{O}$ cavalo está prestes a pisotear uma mulher de vermelho, que segura uma tesoura de ferro com a mão direita e um fuso com a esquerda. Está caída sobre um esquadro. Não há

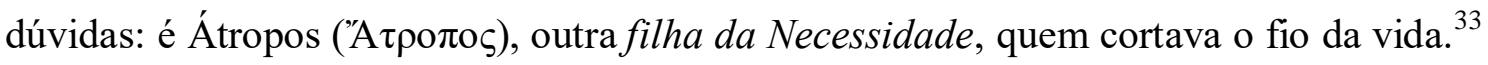
A ausência da terceira irmã, Láquesis ( $\Lambda \alpha ́ \chi \varepsilon \sigma 1 \varsigma)$ é significativa, pois esta era a responsável por prolongar a existência. ${ }^{34}$ Não há lugar para sua representação no palco da morte!

\section{A viela de roda da Morte, melodia do fim}

\section{Imagem 6}

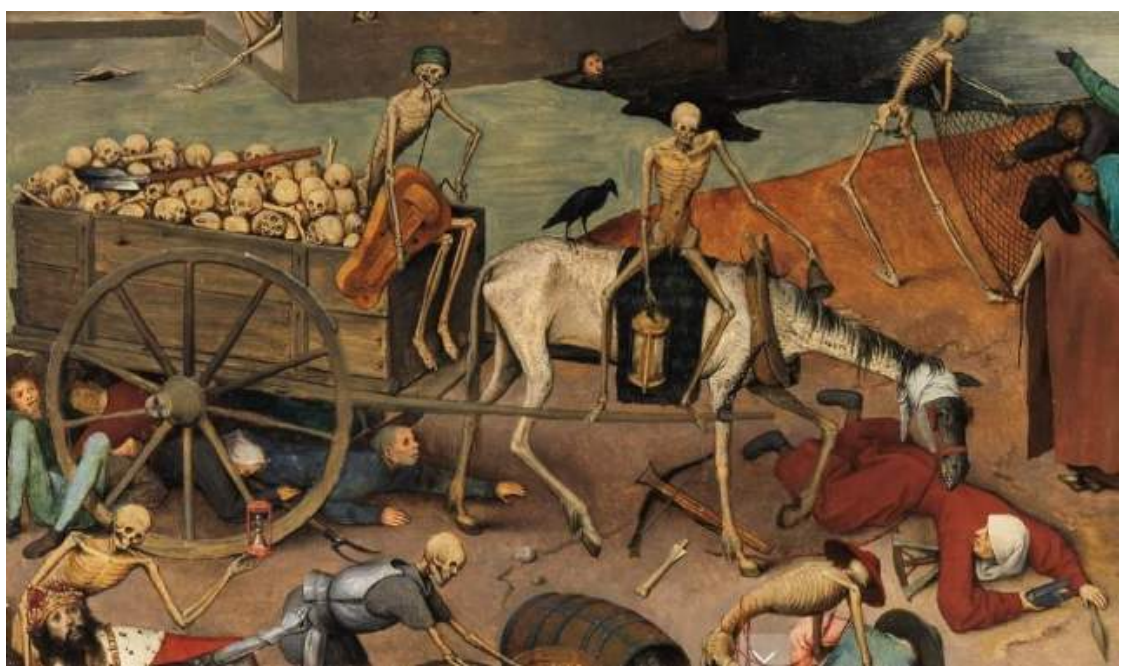

Sentado à frente do carro de boi, há um esqueleto com um chapéu verde - o verde da ambiguidade (a meio caminho entre o azul celeste e o vermelho infernal ${ }^{35}$ ). Atrás de 
outro esqueleto com sineta e candeeiro, ele toca uma enorme viela de roda. Exatamente do lado contrário da cena do trovador e de sua amada. As sonoridades do alaúde (Amor) e da viela de roda (Morte) se opõem. ${ }^{36}$

Instrumento costumeiramente executado em cerimônias seculares, a viela de roda está presa ao pescoço do músico esqueleto por uma alça, para não cair. Bruegel ajusta a viela ao personagem e a representa muito usada, desgastada pelo tempo, como se também estivesse em decomposição, já que o mundo está em ruínas. Tinha duas cordas, com um pequeno teclado que, quando tocado, subia uma pequena alavanca com uma tira de couro que percutia na corda em um determinado ponto, e funcionava como um dedo no violino, enquanto outra corda soava como um bordão, com um som contínuo. ${ }^{37}$

Naturalmente, a sonoridade etérea do continuum grave da viela de roda provocava, com sua alusão metafísica, um sentimento de transcendência, uma analogia ao som do universo, som contínuo do Criador que mantinha os planetas, com seus movimentos igualmente contínuos, unidos em suas $\operatorname{rotas}^{38}$ - como as antigas formas latinas dos palíndromos que são lidos da mesma forma qualquer que seja a ordem da leitura. ${ }^{39} \mathrm{Ou}$, dito de outra forma, com Sua palavra, o Criador semeia e a vida segue sua rota. $^{40}$ É o fio eterno do mundo, condução transformada em melodia da morte pela Morte. $^{41}$

Sons, ruídos e melodias. Tilintar de moedas e gemidos, gritos e badaladas, o canto amoroso trovadoresco com a maviosidade do alaúde, a melancólica lamúria da viela de roda com o estalar e ranger dos esqueletos, das caveiras, dos ossos. Na imaginação de Bruegel, a tão sonhada sinfonia do universo ${ }^{42}$ se transformou em caos dodecafônico infernal. $^{43}$

Por fim, antes de passarmos para a metade superior do Triunfo da Morte, uma última observação iconográfica: na metade inferior, Bruegel estabelece uma linha divisória entre os extremos da musicalidade do amor (à direita) e a da morte (à esquerda) com uma cena intermediária (imagem 7).

Logo acima do peregrino sendo degolado, Bruegel cria essa linha divisória imaginária da metade inferior de seu cenário com uma viva sugestão de movimento criada pela condução do esquife de uma mãe com seu bebê. Um candelabro ao lado sugere que eles acabaram de falecer. Esqueletos-coveiros, vestidos com longas capas 
marrons, sandálias e capuzes negros, puxam o caixão com cordas pretas. Fazem-no com prazer, pois conversam animadamente, satisfeitos que estão com a disseminação de seu horror. A indiferença é marca do fel da vingança: as rodas do caixão passam por cima de outra morta, que jaz abandonada, no chão, ao lado de um úmero e uma espátula. Ambas têm suas cabeças sobre feixes de trigo. Serão alimento para os vermes. ${ }^{44}$

\section{Imagem 7}

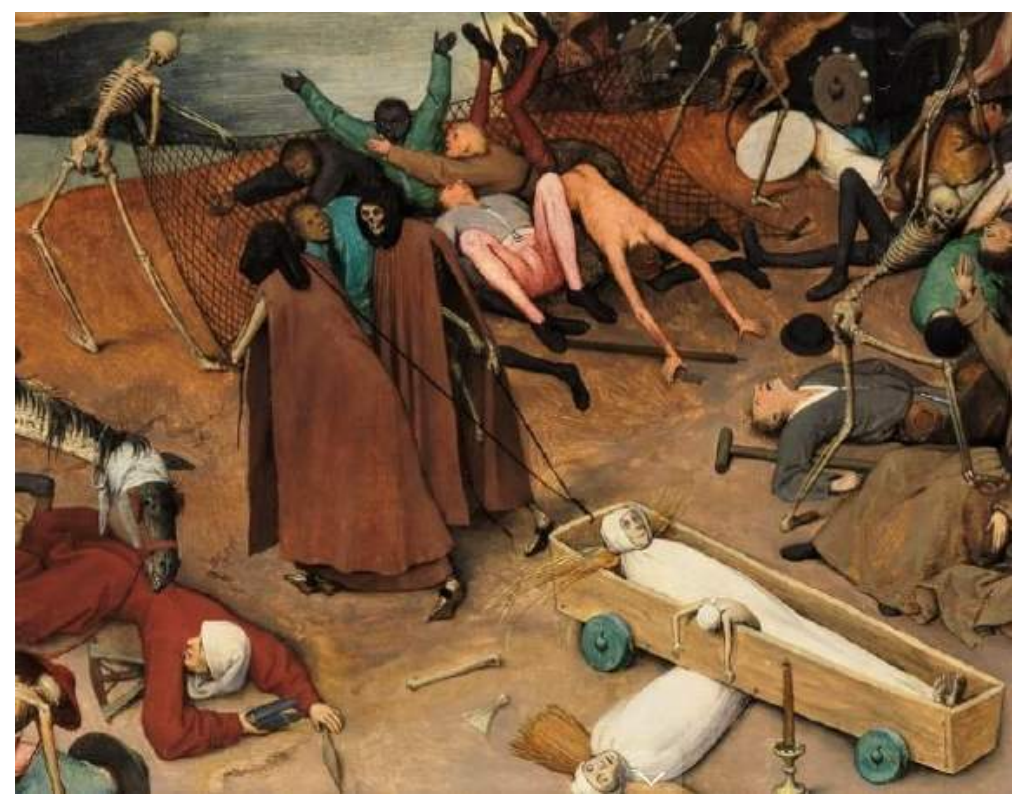

Acima dos esqueletos-coveiros, dois outros esqueletos esticam uma rede com seis pessoas ainda vivas, que se debatem, inutilmente, tentando escapar. Estão desesperadas. Seus corpos gesticulam de múltiplas e atônitas formas, todas a expressar o pânico do desconhecido. Serão jogadas em uma fossa que circunda a torre dos esqueletos com os sinos (imagem 2).

Repare-se no relógio que decora a torre: é um sorridente esqueleto que irradia

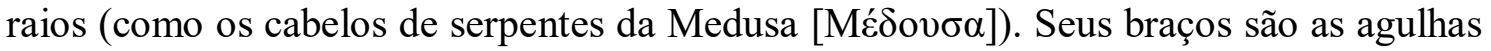
que marcam o tempo! Para deixar o perímetro d'água ainda mais sugestivamente soturno, o pintor pôs um tenebroso e sinuoso abismo negro diante de uma bancada cheia de esqueletos com togas brancas (imagem 8). Três tocam anafis: são os trombeteadores do final dos tempos. ${ }^{45}$ 


\section{Imagem 8}

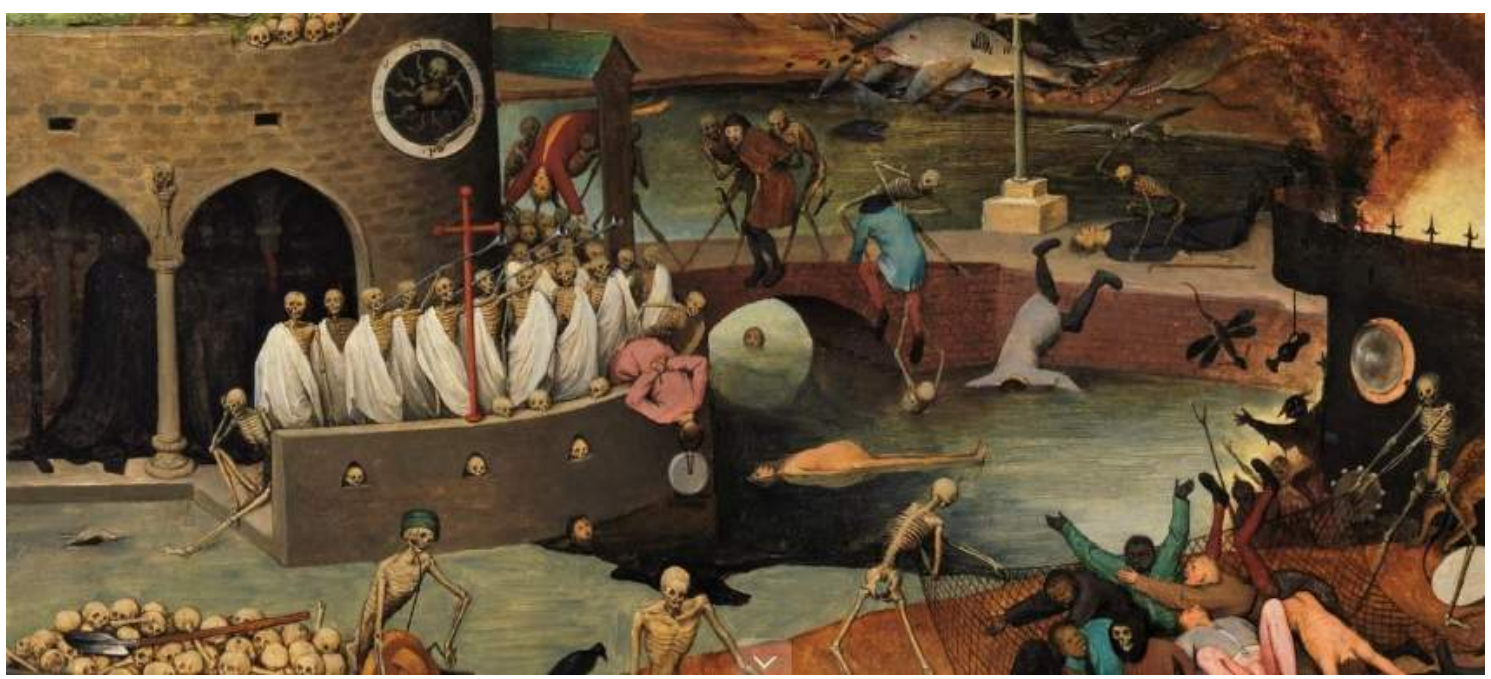

O parapeito de pedra é decorado com caveiras. À frente dos triunfantes anafileiros, uma cruz pomée vermelha, com pomos nas extremidades, símbolo da fé cristã e de seus frutos - seu vermelho rubro pode ser uma alusão ao sangue dos mártires. ${ }^{46}$

Um esqueleto descansa, sentado. Parece enfastiado - sua postura, contemplativa (Omnia sapientia est meditatio mortis), faz alusão à melancolia ${ }^{47}$ (e à teoria galênica dos quatro humores). ${ }^{48}$ Outro inclina um condenado vestido com uma túnica rosa e uma mó de azenha presa ao pescoço. Ele escandalizou as crianças e, por isso, está prestes a ser lançado ao abismo negro, conforme as palavras do Cristo. ${ }^{49} \mathrm{Na}$ água, uma cabeça à mostra, outra embaixo da ponte. Boia um corpo com barriga proeminente. O fosso é dividido pela ponte que dá acesso à torre. Dela, quatro esqueletos jogam dois condenados; um quinto impede um homem de sair da água, e outro, n'água, puxa uma de suas pernas. Mais à direita, um esqueleto levanta sua espada para cortar um infeliz. 
No extremo oposto da torre, outra arde em chamas. Um demônio negro irrompe, de braços abertos, para assustar o observador.

Por seu caráter apregoador - usado para anunciar um arauto - os instrumentos dos macabros anafileiros de Bruegel não são alegorias: eles soam as agudas notas de suas trombetas diante dos aterrorizados gritos dos que serão jogados na fossa mortal. Novamente: imagine-se a sonoridades. Ademais, também por ser utilizado em batalhas, os anafis da cena fazem alusão às (sete) trombetas (retumbantes) de Jericó. ${ }^{50}$ Mas, neste caso, foram as muralhas da vida que tombaram.

O trinômio alaúde/viela de roda/anafil na parte inferior do Triunfo da Morte fundamenta a sonoridade que estrutura a derrota da vida.

\section{A devastadora paisagem}

E deu o mar os mortos que nele havia; e a morte e o inferno deram os mortos que neles havia; e foram julgados cada um segundo as suas obras. Ap 20, 13.

\section{Imagem 9}

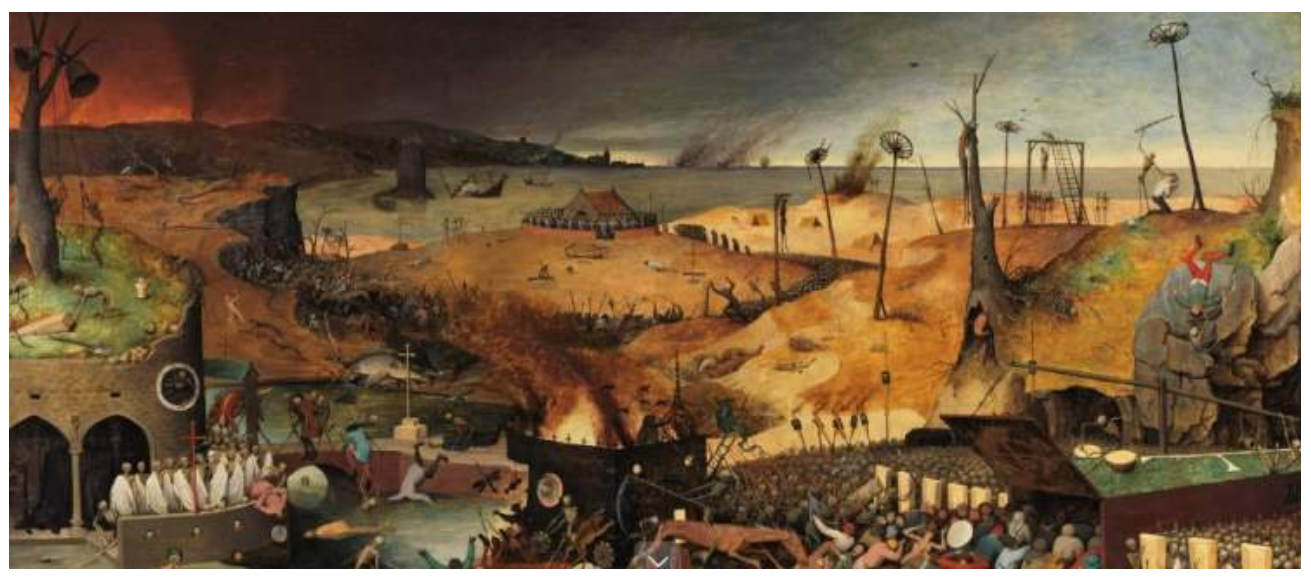

A partir do compacto exército com enormes escudos de madeira com cruzes latinas de São João Evangelista que saem das macabras cavernas (abaixo, à direita) e um enorme caixão que se abre para receber os desesperados que fogem da Morte a cavalo e de suas hostes ${ }^{51}$ - sonoramente recepcionados por uma caveira que toca furiosamente um naqqāra [نقاره] (par de tambores antepassados dos tímpanos, 
executados para fins marciais ${ }^{52}$ ) - o pintor traça uma angustiante linha sinuosa que corta o cenário até as falésias (acima à esquerda), e a curva do litoral, que se une ao horizonte, mar com barcos em chamas.

\section{Imagem 10}

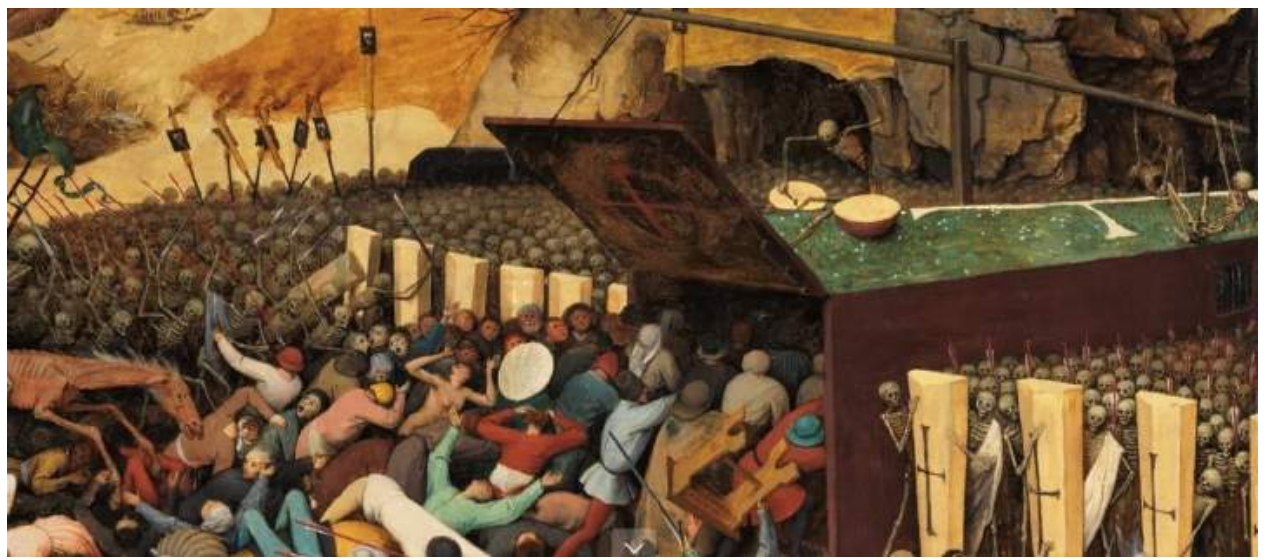

A paisagem da metade superior do Triunfo da Morte é seca, devastada, árida (imagem 11). ${ }^{53}$ Incêndios nas florestas, nos navios. A fumaça escurece o ar. É possível imaginar o som seco dos galhos estalando com o calor do fogo. Da esquerda para a direita, acima do lago em cujas margens peixes apodrecem, uma caveira com dois galgos persegue um dos últimos sobreviventes. ${ }^{54}$

Como boa caçadora de gente, ela leva consigo um corpo, pendurado em uma lança, de cabeça para baixo. Um de seus magérrimos galgos negros morde a perna esquerda do infeliz que, nu, inutilmente se debate e tenta escapar de seu destino: será dilacerado pelos cães. No sopé das enegrecidas falésias, uma furiosa cavalaria de esqueletos com esvoaçantes vestes violetas irrompe e trucida, com longas lanças vermelhas, uma pequena multidão.

Comprimida por um feixe incendiário à sua direita (que divide a multidão que ainda resiste em dois grupos), as pessoas são impiedosamente esmagadas. Não há para onde escapar. À direita, em um promontório, três esqueletos dialogam. São como generais a vislumbrar o avanço de sua cavalaria e sua vitória em campo de batalha. 


\section{Imagem 11}

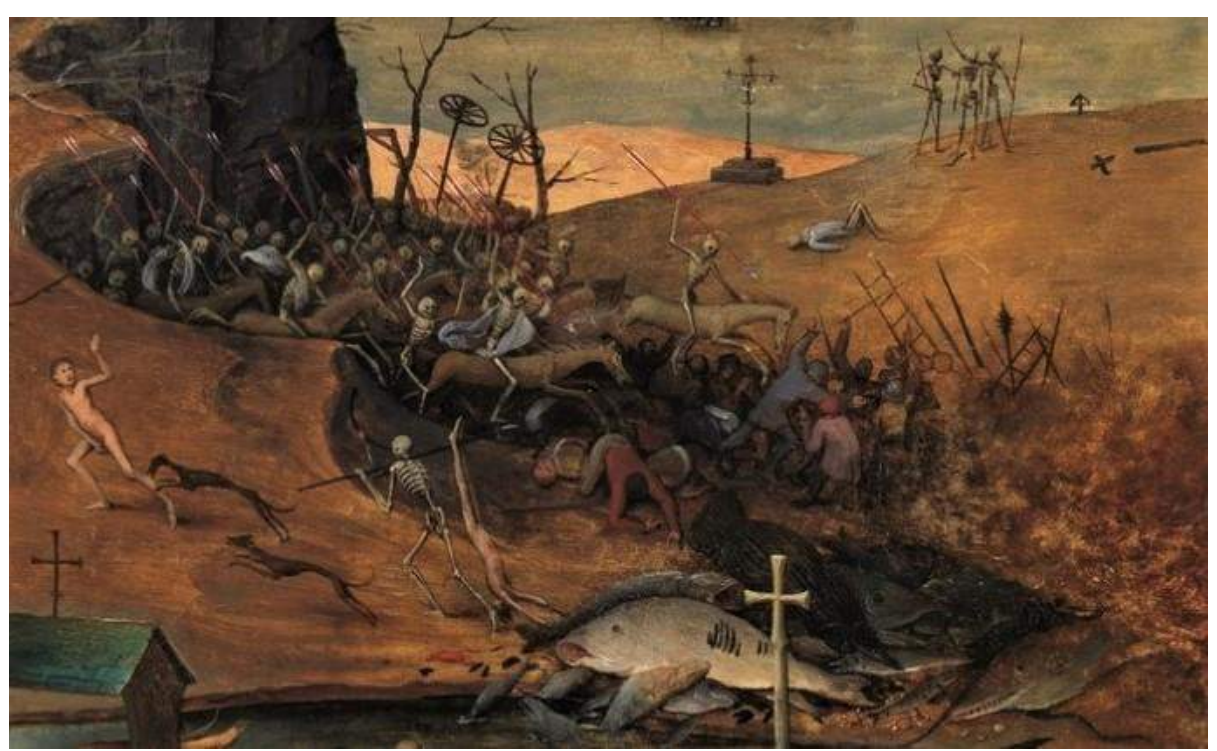

Entre os generais-esqueletos e o massacre, um homem jaz no chão, próximo de um jazigo com uma longa cruz grega flordelisada. As várias e distintas cruzes distribuídas em todo o quadro (latinas, gregas etc.) sugerem que a intenção do artista foi demonstrar a universalidade do sofrimento causado pelo flagelo da morte no cenário europeu à Cristandade, já não mais Christianitas, porque cindida pela Reforma Protestante. $^{55}$

Ademais, não nos esqueçamos das diversas e recorrentes pestes que o continente sofreu, desde o início da Idade Média. ${ }^{56} \mathrm{Com}$ as pernas dobradas, ele ainda não morreu. Só está exausto, derrotado, aguardando seu desenlace.

À direita dos generais-esqueletos, no centro da parte superior de $\underline{O \text { Triunfo } d a}$ Morte, a praia da desolação, do vale de ossos, de Jeremias ${ }^{57}$ e de Ezequiel (imagem 12) ${ }^{58}$ Com o incandescente horizonte de barcos em chamas, alguns a pique, esqueletos desenterram mortos, naturalmente não para a glória de sua ressurreição! ${ }^{59}$ 


\section{Imagem 12}

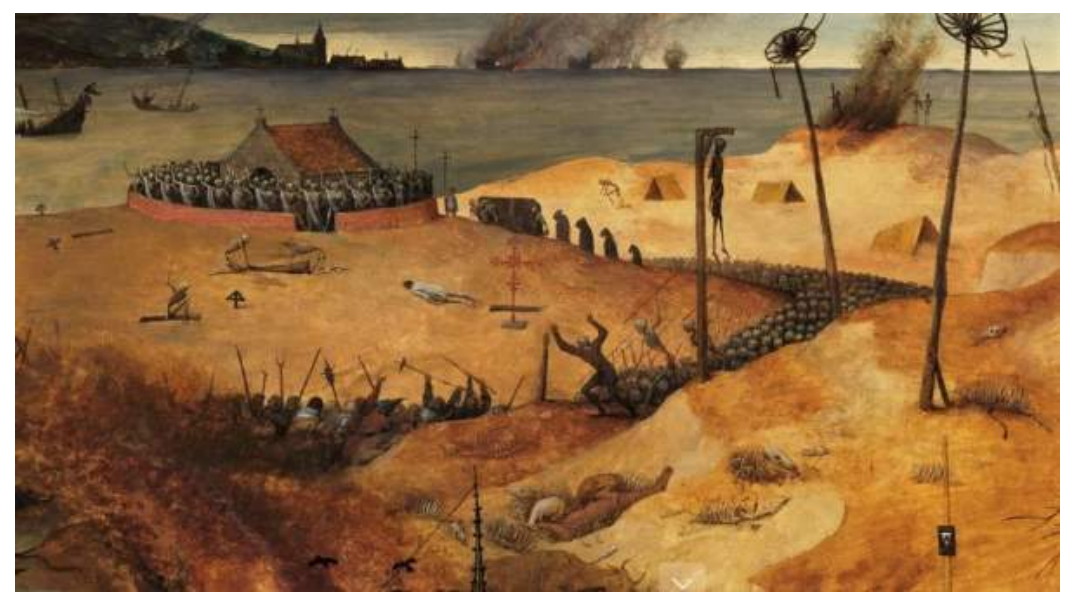

Uma igreja à beira-mar, amuralhada, está repleta de esqueletos, que acenam, como numa espécie de dança macabra, bailado sugerido pelo artista pelo ondular dos esqueletos. Um esquife chega, com quatro monges de hábito e capuz, e é recebido por um clérigo com uma cruz.

Circundando a elevação sobre a qual se situa a igreja, um exército de caveiras, com dois esqueletos à frente empunhando longas lanças vermelhas, ataca multidão que, acossada pelas chamas, luta com espetos, machados e forquilhas.

$\mathrm{Na}$ praia, cabanas e um esqueleto. Ao fundo, quatro pessoas são queimadas vivas, para a satisfação de dois esqueletos que presenciam sua morte. Além de várias ossadas de animais, um corpo enforcado e pessoas executadas em rodas suspensas por longas hastes decoram, morbidamente, o ambiente. ${ }^{60}$

A última cena de minha ordem sequencial iconográfica talvez seja a mais macabra de todas (imagem 13). São quatro acontecimentos, vivos, impactantes (como na metade inferior do quadro, abaixo dela). Em uma enorme árvore queimada, morta, um corpo foi pendurado. É tão macilento e esgarçado que parece um esqueleto. Na raiz, em um 
buraco, uma cena insólita: um homem nu tenta se esconder, mas é atingido por uma das lanças vermelhas dos exércitos de caveiras. A árvore é "decorada" com ossadas.

\section{Imagem 13}

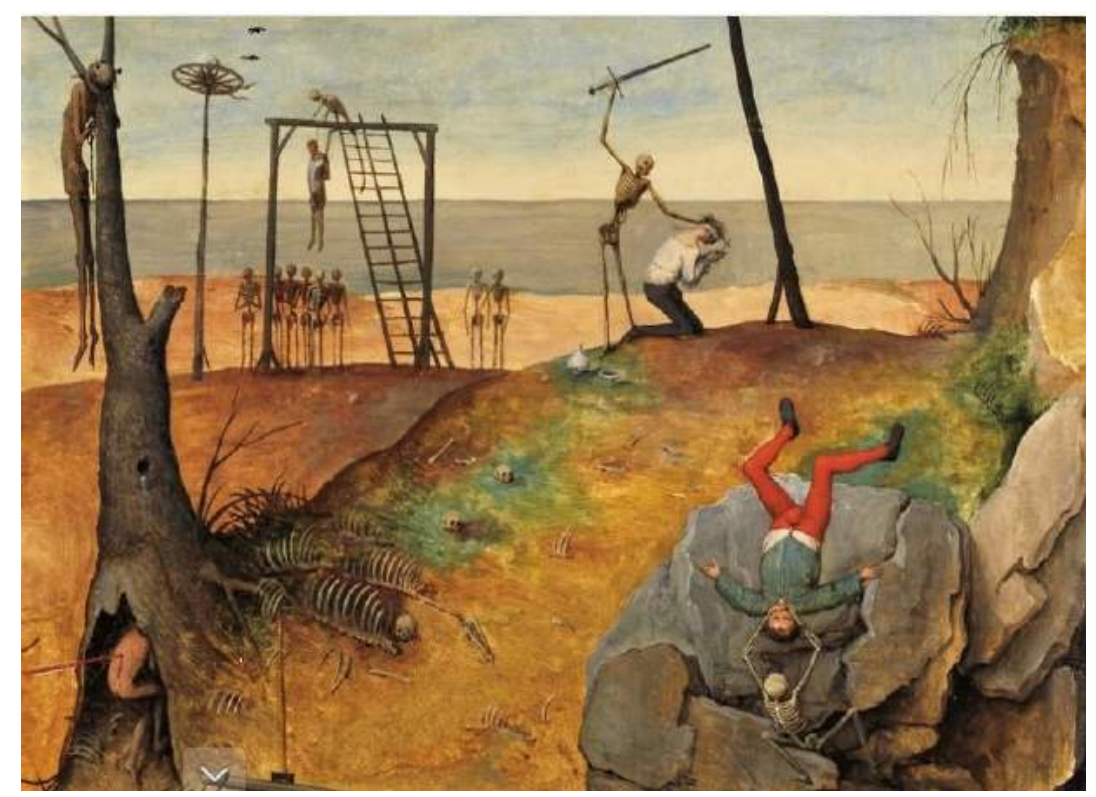

Acima do tronco, ao fundo, nove altivos esqueletos enforcam um homem. À sua direita, outro será degolado. De joelhos, com uma alva (túnica dos supliciados), os cabelos presos por um laço (para não prejudicar o corte do fio da espada), ele reza com um terço nos pulsos e a cruz nas mãos: implora a Deus que o receba em Seus braços não teve sequer o direito a um confessor! ${ }^{61}$ A longa espada erguida pelo verdugo confere uma dramaticidade ainda mais intensa ao instante, pungente. $^{62}$

Por fim, um homem (camponês, por sua vestimenta), de cabeça para baixo, em uma pedreira, é esganado por um sádico esqueleto, que se pendura nele - cena com uma postura corporal muito recorrente na arte medieval, a representar Maomé sofrendo suas penas no Inferno. ${ }^{63}$ 


\section{Conclusão: quem tem ouvidos, ouça!}

Alaúde, viela de roda, anafis, naqqāra. Sinos. A paisagem da morte de Bruegel sugere, indica. Clama: quem tem ouvidos, ouça! ${ }^{64} \mathrm{O}$ cenário do Triunfo da Morte que o artista idealizou explode numa confusa e angustiante miscelânea musical entrecortada por gritos, gemidos e súplicas. Cordas e tímpanos, moedas e espadas, foices e chacoalhar de ossos.

Além de ser uma admoestação imagética de profundo sentido apocalíptico, é um chamado à qualidade cristã da audição quase no mesmo nível do assustador impacto da visão. Melhor: talvez o artista quisesse que não nos esquecêssemos que a tradição ocidental cristã foi fortemente assentada no ato de ouvir ${ }^{65}$, tanto quanto no de ver.

Imagens e sons têm movimento. Sugerem movimento. As aterradoras imagens

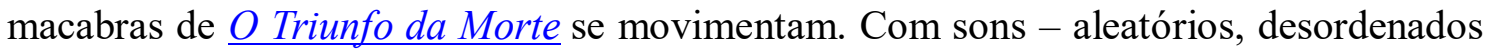
e simultâneos - e imagens - também simultâneas, mas sequenciais e ordenadas. Da esquerda para a direita. É a geografia cristã do Além: não só o coração do sábio está à sua direita e o do tolo à esquerda ${ }^{66}$, mas o próprio Cristo sentenciou que, enquanto as ovelhas ficarão à direita e os bodes à esquerda ${ }^{67}$, esses, à esquerda do Filho do homem, serão apartados para o fogo eterno, preparado para o diabo e seus anjos. ${ }^{68}$ Por isso, todas hostes satânicas da Morte se movimentam no quadro da esquerda para a direita. A Morte vem da esquerda, a vida sucumbe na direita. De ambos os lados, sons diversos. As melodias se movem aleatoriamente, mas num continuum unidimensional. ${ }^{69}$

Por sua vez, as imagens se movem num continuum pluridimensional. São percepções que se cruzam, em desarmonia e desencontro, conflito e angústia. Os desordenados ruídos do mundo não se opõem aos ordenados sons musicais postos por Bruegel. ${ }^{70}$ Esse é o sentido sonoro do caos do Triunfo da Morte. Esses dois movimentos mentais, baseados na visão e na audição, devem estar presentes na apreciação estética de $\underline{O}$ Triunfo da Morte. Deveria também incluir o olfato - imaginar os fétidos odores dos pestilentos ambientes da obra - como obrigação compreensiva. Mas talvez seja pedir demais. No entanto, sem o mundo dos sons, essa impressionante peça de 
Bruegel, $o$ Velho, não estará completa nas emoções estéticas da vida mental de nossa imaginação. ${ }^{71}$ Aliás, a própria vida não se realiza plenamente sem a audição.

$\mathrm{Na}$ contemplação estética calcada na soma dessas possibilidades compreensivas, da audição somada à visão, podemos reconstruir de modo mais completo o mundo apocalíptico imaginado e criado pelo artista. Ou pelo menos nos aproximamos mais dele. Dele e da sua (como também da nossa) única certeza nesta vida: a morte. ${ }^{72}$

Onde está, ó morte, teu aguilhão?

Onde está, ó inferno, tua vitória?

1 Cor 15,55 . 


\section{Bibliografia citada}

ANGOTTI NETO, Hélio, COSTA, Ricardo da. "A lepra medieval e a Medicina metafórica de Ramon Llull (1232-1316)”. In: ANGOTTI NETO, Hélio (org.). Mirabilia Medicince $5(2015 / 2)$, p. 1-30.

ANJOS, Augusto dos. Eu \& Outros Poesias. Volume 1. Rio de Janeiro: Civilização/Itatiaia, 1982.

Armonía de las Esferas. Un libro de consulta sobre la tradición pitagórica en la Música (introd. y ed. Joscelyn Godwin). Girona: Atalanta, 2009.

BALLESTER, Jordi. "An Unexpected Discovery: The Fifteenth-Century Angel Musicians of the Valencia Cathedral". In: Music in Art, vol. 33, n. 1/2 (Spring-Fall 2008). New York: Research Center for Music Iconography, p. 11-29.

BECHERBONNIER, Bernard. Carrascos de Paris: a Dinastia dos Sanson. São Paulo: Editora Mercuryo, 1991.

BLOCK, Daniel Isaac. The Book of Ezekiel. Grand Rapids, Michigan: Eerdmans, 2007.

"Botxí". In: Gran Enciclopèdia Catalana.

BRAUDEL, Fernand. Civilização material, economia e capitalismo: séculos $X V$ XVIII. Volume 2: os jogos das trocas. São Paulo: Martins Fontes, 1996.

BUHIGAS TALLÓN, Jaime. La sinfonía del Universo: en busca de los números que guardan las claves del canon de la belleza y la armonía en el Cosmos. Madrid: La Esfera de los Libros, 2019.

CORNETTE, Jöel. Histoire de la Bretagne et des Bretons. Le Seuil, 2008, 2 vols.

CORTIJO, Antonio; MARTINES, Vicent, e SANTOS, Armando Alexandre (orgs.). Mirabilia Journal 30 (2020/1) - War and Disease in Antiquity and the Middle Ages.

COSTA, Ricardo da. "Maomé foi um enganador que fez um livro chamado Alcorão - A imagem do Profeta na filosofia de Ramon Llull (1232-1316)". In: Revista NOTANDUM, n. 27, Ano XIV, set-dez 2011, p. 19-35, Editora Mandruvá - Univ. do Porto. 
COSTA, Ricardo da. "A Melancolia na Filosofia de Ramon Llull (1232-1316)". In: FREITAS, Verlaine, COSTA, Rachel, FERREIRA, Debora Pazetto (orgs.). $O$ trágico, o sublime e a melancolia. Volume 3. Belo Horizonte: ABRE - Associação Brasileira de Estética, 2016, p. 192-206.

COSTA, Ricardo da. "A Música - Uma das chaves para a compreensão do Tempo". In: COSTA, Ricardo da. Impressões da Idade Média. São Paulo: Livraria Resistência Cultural Editora, 2017, p. 43-61.

COSTA, Ricardo da, e SILVA, Matheus Corassa da. "O Regimen sanitatis (1308) de Arnau de Vilanova (c.1238-1311) e sua prescrição da boa dieta". In: eHumanista 34 (2016). Journal of Iberian Studies, p. 463-480.

COSTA, Ricardo da; GABY, André; HARTMANN, Ernesto; RIBEIRO, Antônio Celso, e SILVA, Matheus Corassa da. "Um tributo à arte de ouvir - O amor cortês nas cançons de Berenguer de Palou (c. 1160-1209)". In: eHumanista/IVITRA 15 (2019), p. 396-455.

COSTA, Ricardo da; LEMOS, Vinicius Saebel; NEVES, Alexandre Emerick; SILVA, Matheus Corassa da. O Descendimento. Novas expressões na Arte (sécs. XIV$X V)$. Artigo inédito. Disponível na Internet.

DELUMEAU, Jean (dir.). Histoire de la Bretagne. Privat, 2000.

DELUMEAU, Jean. A civilização do Renascimento. Lisboa: Edições 70, 2017.

DÍAZ MARROQUIN, Lucía. La Retórica de los Afectos. Kassel: Edition Reichenberger, 2008.

ECO, Umberto (org.). História da Feiúra. Rio de Janeiro: Record, 2007.

ECO, Umberto (org.). Idade Média. Lisboa: Publicações Dom Quixote, 04 volumes, 2014-2015.

FRANCO JÚNIOR, Hilário. "Similibus simile cognoscitur. O pensamento analógico medieval". In: Medievalista 14, julho-dezembro de 2013, p. 1-37.

FRIEDLAND, Paul. Seeing Justice Done: The Age of Spectacular Capital Punishment in France. Oxford University Press, 2014. 
GANUZA, Carina. "Teorías para la construcción del poder temporal: el papado y la Iglesia en el Occidente europeo (siglos X-XIII)". In: Enfoques XXIII, n. 1 (otoño 2011), Universidad Adventista del Plata, Libertador San Martín, Argentina, p. 75-100.

GINZBURG, Carlo. Indagações sobre Piero. O Batismo - O Ciclo de Arezzo - A Flagelação. Rio de Janeiro: Paz e Terra, 1989.

GONZAGA, João Bernardino. A Inquisição em seu mundo. São Paulo: Saraiva, 1993.

GONZÁLEZ DE ZÁRATE, Jesús María. "Pieter Brueghel. Triunfo de la Muerte". In: BROCAR. Cuadernos de Investigación Histórica 38, Universidad de la Rioja, 2014, p. $145-162$.

HARRINGTON, Joel F. The Faithful Executioner: Life and Death, Honor and Shame in the Turbulent Sixteenth Century. New York: Farrar, Straus and Giroux, 2013.

HARRISON, Carol. The Art of Listening in the Early Church. Oxford University Press, 2013.

HOLMES, Stephen R. Listening to the Past. The place of Tradition in Theology: on the Theory and Practice of Historical Theology. Paternoster Press, 2002.

ISMAEL MARTÍNEZ, O. Carm. Los Carmelitas. Historia de la Orden del Carmen. VI. Figuras del Carmelo. Madrid: Biblioteca de Autores Cristianos (BAC), 1996.

JENSON, Robert W. Ezekiel. Grand Rapids, Michigan: Brazos Press, 2009.

JOVER PERIS, Ivan. "Moiras: les filadores del destí". In: Alberri 22. Quaderns d'investigació del Centre d'Estudis Contestants, 2012, p. 95-116.

KAPLAN, Debra. Beyond expulsion: Jews, Christians, and Reformation Strasbourg. Stanford University Press, 2011.

KAPLAN, Debra. "Jews in Early Modern Europe: The Sixteenth and Seventeenth Centuries”. In: History compass 10 (2012), p. 191-206.

KLEIN, Ralph W. Ezekiel: The Prophet and his Message. Columbia: University of South Carolina Press, 1988.

LE GOFF, Jacques. El Dios de la Edad Media. Madrid: Editorial Trotta, 2004. 
MAGNANI, Sérgio. Expressão e Comunicação na Linguagem da Música. Belo Horizonte: Editora da UFMG, 1989.

MARIUS, Richard. Martin Luther: The Christian Between God and Death. Harvard University Press, 1999.

MCGEE, Timothy J. (ed.). Instruments and their Music in the Middle Ages. Aldershot: Ashgate, 2009.

OLIVER, Antonio. “Ecclesia y Christianitas en Inocencio III”. In: Estudios Lulianos. Revista cuatrimestral de Investigación Luliana y Medievalística (EL). Palma de Mallorca: Maioricensis Schola Lullística, Instituto Internacional del Consejo Superior de Investigaciones Cientificas, vol. I, 1957, p. 217-244.

PACAUT, Marcel. "A Europa pontifícia ou o tempo da cristandade (Meados do século XII - Final do século XIII)". In: LIVET, GEORGES e MOUSNIER, ROLAND MOUSNIER (dir.). História Geral da Europa I. Lisboa, Publicações Europa-América, 1996, p. 441-567.

PAWLAK, Anna. “The Imaginarium of Death. Pieter Bruegel's The Triumph of Death". In: KASCHEK, Bertram; MÜLLER, Jürgen; BUSKIRK, Jessica (eds.). Pieter Bruegel the Elder and Religion. Leiden, 2018, p. 134-158.

PEDREL, Felipe. Diccionario técnico de la Música. Valladolid: Editorial MAXTOR, 2009.

PLATÃO. A República (trad.: Carlos Alberto Nunes). Belém: EDUFPA, 2000.

PLATH, Sylvia. "Two views of a cadaver room". In: Learning Poetry \& Performance. British Library.

PONS GIL, Crístian. Comportamiento acústico de los instrumentos de percusión en la Orquesta. Catalunya: Escuela Superior de Música de Catalunya (ESMC), 2015

REMNANT, Mary. Historia de los Instrumentos musicales. Barcelona: Manon Troppo, Ediciones Robinbook, 2002.

ROCHE ARNES, Pedro (coord.). El pensamiento político en la Edad Media. Madrid: Fundación Ramón Areces, 2010. 
ROSE, Adrian. "Angel Musicians in the Medieval Stained Glass of Norfolk Churches". In: Early Music, vol. 29, n. 2 (May, 2001), Oxford University Press, p. 186217.

ROSE, Jacqueline. The Haunting of Sylvia Plath. London: Virago Press, 1991.

SADIE, Stanley; LATHAM, Alison (eds.). The Grove Concise Dictionary of Music. Macmillan, 1988.

SAN AGUSTÍN. Obras de San Agustín. Tomo XVII. Madrid: BAC, 1958.

SANTOS, Armando Alexandre dos. O vício capital da inveja, leitmotiv e fio condutor de "Curial e Guelfa". Análise da tradução ao português e estudo cultural e sintático-semântico. Alicante, tesis doctoral, noviembre de 2018

SANTOS JÚNIOR, Cristóvão José dos; SANTOS SOBRINHO, José Amarante. "Elementos da tradição palindrômica antiga". In: Afluente - Revista de Letras e Linguística, UFMA/Campus III, v. 4, n. 13, p. 195-213, set./dez. 2019.

SCRUTON, Roger. Understanding Music. Philosophy and Interpretation. London: Continuum, 2009.

SCRUTON, Roger. Coração devotado à morte. O sexo e o Sagrado em Tristão e Isolda, de Wagner. São Paulo: É Realizações, 2010.

SCRUTON, Roger. O rosto de Deus. São Paulo: É Realizações, 2015.

SCRUTON, Roger. Arte e Imaginação. Um estudo em filosofia da mente. São Paulo: É Realizações, 2017.

SILVER, Larry. "Morbid fascination: Death by Bruegel". In: MELION, Walter S.; ROTHSTEIN, Bret; WEEMANS, Michel (eds.). The Anthropomorphism Lens. Anthropomorphism, Microcosmism and Analogy in Early Modern Thought and Visual Arts. Leiden/Boston: Brill, 2015, p. 421-454.

SNYDER, James; SILVER, Larry; LUTTIKHUIZEN, Henry. Northern Renaissance Art: Painting, Sculpture, the Graphic Arts from 1350 to 1575. Prentice Hall, 2005.

SOUSA, Jorge Prata de, COSTA, Ricardo da. "Corpo \& alma, vida \& morte na medicina ibérica medieval. O Regimento proveitoso contra a pestilência (c. 1496)". In: 
História, Ciência, Saúde - Manguinhos. Rio de Janeiro: Casa de Oswaldo Cruz/Fundação Oswaldo Cruz, set.-dez. 2005, volume XII, número 3, p. 841-851.

SPIERENBURG, Pieter. The Spectacle of Suffering: Executions and the Evolution of Repression: from a Preindustrial Metropolis to the European Experience. Cambridge University Press, 1984.

VORSATZ, Ingrid. “A ironia trágica, a equivocidade da linguagem e a dimensão ética: nota sobre a Ode ao Homem na Antígona de Sófocles”. In: Tempo psicanal., Rio de Janeiro, v. 45, n. 1, p. 135-145, jun. 2013.

WALKER-MEIKLE, Kathleen. Medieval dogs. British Library, 2013.

WEBBER, Frederick Roth. Church symbolism. An explanation of the more important symbols of the Old and New Testament, the primitive, the mediaeval and the modern church. J. H. Jansen Publisher, Cleveland, 1938.

WISNIK, José Miguel. O som e o sentido. Uma outra história das músicas. São Paulo: Companhia das Letras, 1989.

WOODWARD, Richard B. "Death Takes No Holiday". In: The Wall Street Journal, February 14, 2009. 


\title{
Notas
}

\begin{abstract}
${ }^{1}$ SILVER, Larry. "Morbid fascination: Death by Bruegel". In: MELION, Walter S.; ROTHSTEIN, Bret; WEEMANS, Michel (eds.). The Anthropomorphism Lens. Anthropomorphism, Microcosmism and Analogy in Early Modern Thought and Visual Arts. Leiden/Boston: Brill, 2015, p. 421-454.

2 "Assim disse o Senhor Deus: Vivo eu, que os que estiverem em lugares desertos, cairão à espada, e o que estiver em campo aberto o entregarei às feras, para que o devorem, e os que estiverem em lugares fortes e em cavernas morrerão de peste. E tornarei a terra em desolação e espanto e cessará a soberba do seu poder; e os montes de Israel ficarão tão desolados que ninguém passará por eles” (Ez 33, 27-28).

Para o Profeta Ezequiel, ver BLOCK, Daniel Isaac. The Book of Ezekiel. Grand Rapids, Michigan: Eerdmans, 2007; JENSON, Robert W. Ezekiel. Grand Rapids, Michigan: Brazos Press, 2009 e KLEIN, Ralph W. Ezekiel: The Prophet and his Message. Columbia: University of South Carolina Press, 1988.
\end{abstract}

${ }^{3}$ FRANCO JÚNIOR, Hilário. "Similibus simile cognoscitur. O pensamento analógico medieval". In: Medievalista 14, julho-dezembro de 2013, p. 1-37. Para a importância da Bíblia - e consequentemente dos estudos teológicos - para os estudos históricos a respeito da Idade Média, ver LE GOFF, Jacques. El Dios de la Edad Media. Madrid: Editorial Trotta, 2004.

${ }^{4}$ GINZBURG, Carlo. Indagações sobre Piero. O Batismo - O Ciclo de Arezzo - A Flagelação. Rio de Janeiro: Paz e Terra, 1989.

${ }^{5}$ Proposta metodológica já trabalhada em COSTA, Ricardo da. "A Música - Uma das chaves para a compreensão do Tempo". In: COSTA, Ricardo da. Impressões da Idade Média. São Paulo: Livraria Resistência Cultural Editora, 2017, p. 43-61.

${ }^{6}$ SCRUTON, Roger. Coração devotado à morte. O sexo e o Sagrado em Tristão e Isolda, de Wagner. São Paulo: É Realizações, 2010.

${ }^{7}$ DÍAZ MARROQUIN, Lucía. La Retórica de los Afectos. Kassel: Edition Reichenberger, 2008.

${ }^{8}$ Para esse universo da linguagem da ironia trágica, ver VORSATZ, Ingrid. "A ironia trágica, a equivocidade da linguagem e a dimensão ética: nota sobre a Ode ao Homem na Antígona de Sófocles". In: Tempo psicanal., Rio de Janeiro, v. 45, n. 1, p. 135-145, jun. 2013.

9 PAWLAK, Anna. "The Imaginarium of Death. Pieter Bruegel's The Triumph of Death". In: KASCHEK, Bertram; MÜLLER, Jürgen; BUSKIRK, Jessica (eds.). Pieter Bruegel the Elder and Religion. Leiden, 2018, p. 137.

${ }^{10}$ Um tema imagético muito recorrente no séc. XVI (e herdeiro direto da tradição medieval) é o da orquestra angélica celeste (com distintos instrumentos musicais). Para alguns exemplos do tema, ver ROSE, Adrian. "Angel Musicians in the Medieval Stained Glass of Norfolk Churches". In: Early Music, vol. 29, n. 2 (May, 2001), Oxford University Press, p. 186-217; BALLESTER, Jordi. "An Unexpected Discovery: The Fifteenth-Century Angel Musicians of the Valencia Cathedral". In: Music in Art, vol. 33 , n. 1/2 (Spring-Fall 2008). New York: Research Center for Music Iconography, p. 11-29.

${ }^{11}$ Para uma apreciação a respeito dos temas poéticos do amor cortês e suas nuances musicais, ver COSTA, Ricardo da; GABY, André; HARTMANN, Ernesto; RIBEIRO, Antônio Celso, e SILVA, Matheus Corassa da. "Um tributo à arte de ouvir - $\mathrm{O}$ amor cortês nas cançons de Berenguer de Palou (c. 1160-1209)". In: eHumanista/IVITRA 15 (2019), p. 396-455.

${ }^{12}$ MCGEE, Timothy J. (ed.). Instruments and their Music in the Middle Ages. Aldershot: Ashgate, 2009.

13 Agradeço sobremaneira a explicação a respeito dos instrumentos medievais/renascentistas proporcionada pelo Prof. Dr. Antonio Celso Ribeiro (UFES).

${ }^{14}$ Tratei do tema da melancolia em COSTA, Ricardo da. "A Melancolia na Filosofia de Ramon Llull (1232-1316)". In: FREITAS, Verlaine, COSTA, Rachel, FERREIRA, Debora Pazetto (orgs.). O trágico, o sublime e a melancolia. Volume 3. Belo Horizonte: ABRE - Associação Brasileira de Estética, 2016, p. 192-206.

${ }^{15}$ Estilo poético-confessional norte-americano (anos 50-60) com ênfase nas experiências pessoais mais extremas - loucura, sexualidade, suicídio etc. - relacionadas a temas sociais e, por isso, oposto ao ambiente "feliz" do american way of life. Ver ROSE, Jacqueline. The Haunting of Sylvia Plath. London: Virago Press, 1991.

${ }^{16}$ Citado em ECO, Umberto (org.). História da Feiúra. Rio de Janeiro: Record, 2007, p. 69.

${ }^{17}$ PLATH, Sylvia. "Two views of a cadaver room". In: Learning Poetry \& Performance. British Library.

${ }^{18}$ Também citado em ECO, Umberto (org.). História da Feiúra, op. cit., p. 69. 
19 "E, havendo aberto o quarto selo, ouvi a voz do quarto animal, que dizia: Vem, e vê. E olhei, e eis um cavalo amarelo, e o que estava assentado sobre ele tinha por nome Morte; e o inferno o seguia; e foi-lhes dado poder para matar a quarta parte da terra, com espada, e com fome, e com peste, e com as feras da terra" (Ap 6, 7-8).

GONZÁLEZ DE ZÁRATE, Jesús María. "Pieter Brueghel. Triunfo de la Muerte". In: BROCAR. Cuadernos de Investigación Histórica 38, Universidad de la Rioja, 2014, p. 149.

${ }^{20}$ Ordem criada no séc. XII que recebeu um grande impulso religioso (e filosófico) no XVI pelas figuras de Santa Teresa de Jesus (1515-1582) e São João da Cruz (1542-1591). Ver ISMAEL MARTínEZ, O. Carm. Los Carmelitas. Historia de la Orden del Carmen. VI. Figuras del Carmelo. Madrid: Biblioteca de Autores Cristianos (BAC), 1996.

${ }^{21}$ O curador sênior de pinturas flamengas e do norte da Europa do Museo Nacional del Prado, Dr. Alejandro Vergara, recorda, a respeito do soldado de rojo: "Formalmente es un escorzo, herencia de la cultura clásica. Bruegel ha viajado a Italia y hace un guiño a los ideales del arte italiano. Los pliegues de la ropa también son clásicos." - "Alejandro Vergara, experto del Museo del Prado, explica el cuadro El triunfo de la muerte, de Pieter Bruegel y desentraña las claves ocultas que esconde la obra". In: $\underline{X L}$ Semanal.

${ }^{22} \mathrm{O}$ Renascimento, o Humanismo, as reformas protestantes e católicas e a Revolução Científica alteraram profundamente a vida de cristãos e judeus na Europa. Por exemplo, a cultura judaica tornou-se no séc. XV uma das componentes do Humanismo. Para a situação geral dos judeus na Europa do período, ver KAPLAN, Debra. "Jews in Early Modern Europe: The Sixteenth and Seventeenth Centuries". In: History compass 10 (2012), p. 191-206 e, da mesma autora, Beyond expulsion: Jews, Christians, and Reformation Strasbourg. Stanford University Press, 2011. E também DELUMEAU, Jean. A civilização do Renascimento. Lisboa: Edições 70, 2017, e BRAUDEL, Fernand. Civilização material, economia e capitalismo: séculos XV-XVIII. Volume 2: os jogos das trocas. São Paulo: Martins Fontes, 1996.

${ }^{23}$ MARIUS, Richard. Martin Luther: The Christian Between God and Death. Harvard University Press, 1999

${ }^{24}$ SCRUTON, Roger. O rosto de Deus. São Paulo: É Realizações, 2015, p. 108.

${ }^{25}$ É possível que a alusão ao ducado da Bretanha no manto do rei indique que se trata do monarca da França: com a morte de Francisco II (1488), duque da Bretanha, e o casamento de sua filha, a duquesa Ana I (1477-1514) com Carlos VIII da França (1470-1498) em 1491, este adquiriu o título de duque da Bretanha iure uxoris (por direito de sua mulher). A coroa ducal uniu-se à coroa francesa em 1532, graças a uma votação das cortes bretãs após a morte da rainha Cláudia da França (1499-1524), última duquesa soberana (Edito de Plessis-Macé). Ver DELUMEAU, Jean (dir.). Histoire de la Bretagne. Privat, 2000, e CORNETTE, Jöel. Histoire de la Bretagne et des Bretons. Le Seuil, 2008, 2 vols.

${ }^{26}$ PONS GIL, Crístian. Comportamiento acústico de los instrumentos de percusión en la Orquesta. Catalunya: Escuela Superior de Música de Catalunya (ESMC), 2015, p. 34.

27 "Porque nada trouxemos para este mundo, e manifesto é que nada podemos levar dele. Tendo, porém, sustento, e com que nos cobrirmos, estejamos com isso contentes. Mas os que querem ser ricos caem em tentação, e em laço, e em muitas concupiscências loucas e nocivas, que submergem os homens na perdição e ruína. Porque o amor ao dinheiro é a raiz de toda a espécie de males; e nessa cobiça alguns se desviaram da fé, e se traspassaram a si mesmos com muitas dores. Mas tu, ó homem de Deus, foge destas coisas, e segue a justiça, a piedade, a fé, o amor, a paciência, a mansidão" (1 Tm 6, 7-11). O rei de Bruegel não foi um homem de Deus!

28 "Vês! Ninguém assistiu ao formidável / Enterro de tua última quimera. / Somente a Ingratidão - esta pantera - / Foi tua companheira inseparável! / Acostuma-te à lama que te espera! / O Homem, que, nesta terra miserável, / Mora, entre feras, sente inevitável / Necessidade de também ser fera. / Toma um fósforo. Acende teu cigarro! / O beijo, amigo, é a véspera do escarro, / A mão que afaga é a mesma que apedreja. /Se a alguém causa inda pena a tua chaga, / Apedreja essa mão vil que te afaga, / Escarra nessa boca que te beija!" - ANJOS, Augusto dos. Eu \& Outros Poesias. Volume 1. Rio de Janeiro: Civilização/Itatiaia, 1982, p. 117.

${ }^{29}$ Ver ROCHE ARNES, Pedro (coord.). El pensamiento político en la Edad Media. Madrid: Fundación Ramón Areces, 2010; GANUZA, Carina. "Teorías para la construcción del poder temporal: el papado y la Iglesia en el Occidente europeo (siglos X-XIII)". In: Enfoques XXIII, n. 1 (otoño 2011), Universidad Adventista del Plata, Libertador San Martín, Argentina, p. 75-100.

${ }^{30}$ WOODWARD, Richard B. "Death Takes No Holiday". In: The Wall Street Journal, February 14, 2009.

${ }^{31}$ Curiosamente, em Portugal, no Minho (histórica província ao norte), a palavra candeeiro também designa a pessoa que vai à frente do carro de bois. 
32 "Três outras figuras femininas estavam sentadas à volta, com intervalos iguais, cada uma no seu trono, as Moiras, filhas da Necessidade, com vestimenta branca e fitas na cabeça: Láquese, Cloto e Átropos, as quais acompanhavam com seu canto a harmonia das sereias: Láquese o passado; Cloto o presente, e Átropos o futuro." - PLATÃO. A República (trad.: Carlos Alberto Nunes). Belém: EDUFPA, 2000, p. $465(617 \mathrm{c})$.

${ }^{33}$ PAWLAK, Anna. "The Imaginarium of Death. Pieter Bruegel's The Triumph of Death", op. cit., p. 143.

${ }^{34}$ Para as três Moiras, ver JOVER PERIS, Ivan. "Moiras: les filadores del destî". In: Alberri 22. Quaderns d'investigació del Centre d'Estudis Contestants, 2012, p. 95-116.

${ }^{35}$ COSTA, Ricardo da; LEMOS, Vinicius Saebel; NEVES, Alexandre Emerick; SILVA, Matheus Corassa da. O Descendimento. Novas expressões na Arte (sécs. XIV-XV). Artigo inédito. Disponível na Internet.

${ }^{36}$ Naturalmente essa oposição analógica e imagética alaúde $x$ viela de roda/amor $x$ morte que se encontra nesse quadro de Bruegel não é recorrente nas representações artísticas em que há vielas de roda. Pelo menos nos séculos seguinte. Por exemplo, nos sécs. XVII-XVIII, Adriaen van Ostade (1610-1685), David Teniers, o Jovem (1610-1690) e Jean-Antoine Watteau (1684-1721) situam socialmente a viela de roda em casamentos rurais e festas campesinas - Festival e festa da vila (1637, de David Teniers, $o$ Jovem), Concerto rústico (1638, de van Ostade), Celebração rural (1647, de David Teniers, o Jovem) e Contrato de casamento e dança rural (c. 1711, de Jean-Antoine Watteau).

${ }^{37}$ REMNANT, Mary. Historia de los Instrumentos musicales. Barcelona: Manon Troppo, Ediciones Robinbook, 2002.

${ }^{38}$ Armonía de las Esferas. Un libro de consulta sobre la tradición pitagórica en la Música (introd. y ed. Joscelyn Godwin). Girona: Atalanta, 2009.

39 SANTOS JÚNIOR, Cristóvão José dos; SANTOS SOBRINHO, José Amarante. "Elementos da tradição palindrômica antiga". In: Afluente - Revista de Letras e Linguística, UFMA/Campus III, v. 4, n. 13, p. 195-213, set./dez. 2019.

40 "E ele disse: A vós vos é dado conhecer os mistérios do reino de Deus, mas aos outros por parábolas, para que vendo, não vejam, e ouvindo, não entendam. Esta é, pois, a parábola: a semente é a palavra de Deus" (Lc 8, 10-11).

${ }^{41}$ Todos os parágrafos acima a respeito da viela de roda foram retirados de uma aula do Prof. Dr. Antonio Celso Ribeiro (UFES), a quem agradecemos pela gentileza da explicação - e erudição.

${ }^{42}$ BUHIGAS TALLÓN, Jaime. La sinfonía del Universo: en busca de los números que guardan las claves del canon de la belleza y la armonía en el Cosmos. Madrid: La Esfera de los Libros, 2019.

${ }^{43}$ A primeira audição que me vem à mente para relacionar uma suposta ausência de ordem e de hierarquia do sistema dodecafônico se comparado ao sistema tradicional - baseado em tensões e relaxamentos que proporcionavam um senso de coesão, um discurso fluido e gerava uma previsibilidade por estar assentado na memória ocidental - ao caos sonoro do Triunfo da Morte de Bruegel é um álbum de John Adams (1947-), Must the Devil have all the good tunes? (Deutsche Grammophon, 2020), concerto para piano e orquestra com três movimentos com a Los Angeles Philharmonic (dir. art.: Gustave Dudamel; pianista: Yuja Wang) - curiosamente, o título do concerto é de uma frase atribuída a Lutero (1483-1546) que possivelmente alude às seduções provocadas pela arte secular. Para uma abordagem filosófica da Música, ver SCRUTON, Roger. Understanding Music. Philosophy and Interpretation. London: Continuum, 2009. Ver também MAGNANI, Sérgio. Expressão e Comunicação na Linguagem da Música. Belo Horizonte: Editora da UFMG, 1989.

44 "No suor do teu rosto comerás o teu pão, até que te tornes à terra; porque dela foste tomado; porquanto és pó e em pó te tornarás" (Gn 3,19).

${ }^{45} \mathrm{O}$ anafil (do árabe hispânico annafír e este do árabe clássico nafír) era uma trombeta natural (sem válvulas), reta, mourisca, com, no mínimo, $80 \mathrm{~cm}$ de comprimento (as maiores poderiam ter até dois metros), "...nunca ha sido considerado como instrumento artístico de concierto sino de guerra, torneo ó pública reunión" - PEDREL, Felipe. Diccionario técnico de la Música. Valladolid: Editorial MAXTOR, 2009, p. 17.

${ }^{46}$ Para o simbolismo das cruzes, o clássico é WEBBER, Frederick Roth. Church symbolism. An explanation of the more important symbols of the Old and New Testament, the primitive, the mediaeval and the modern church. Cleveland, J. H. Jansen Publisher, 1938.

${ }^{47}$ PAWLAK, Anna. "The Imaginarium of Death. Pieter Bruegel's The Triumph of Death", op. cit., p. 150-151.

${ }^{48}$ COSTA, Ricardo da. "A Melancolia na filosofia de Ramon Llull (1232-1316)”, op. cit. 
49 "E qualquer que receber em meu nome um menino, tal como este, a mim me recebe. Mas qualquer que escandalizar um destes pequeninos que creem em mim, melhor lhe fora que se lhe pendurasse ao pescoço uma mó de azenha, e se submergisse na profundeza do mar" (Mt 18, 5-6), e "E disse aos discípulos: É impossível que não venham escândalos, mas ai daquele por quem vierem! Melhor the fora que lhe pusessem ao pescoço uma mó de atafona, e fosse lançado ao mar, do que fazer tropeçar um destes pequenos" (Lc 17, 1-2).

50 "O povo clamou e os sacerdotes tocaram as trombetas. E logo que o povo ouviu o som das trombetas, levantou um grande clamor. A muralha desabou. A multidão subiu à cidade, sem nada diante de si” (Js 6, 20).

${ }^{51}$ PAWLAK, Anna. "The Imaginarium of Death. Pieter Bruegel's The Triumph of Death", op. cit., p. 145.

${ }^{52}$ SADIE, Stanley; LATHAM, Alison (eds.). The Grove Concise Dictionary of Music. Macmillan, 1988, p. 514.

${ }^{3}$ SNYDER, James; SILVER, Larry; LUTTIKHUIZEN, Henry. Northern Renaissance Art: Painting, Sculpture, the Graphic Arts from 1350 to 1575. Prentice Hall, 2005, p. 486.

${ }^{54} \mathrm{O}$ galgo (gallicus canis) era considerado nobre na Idade Média. Na Espanha, era protegido por diversos Fueros (de Salamanca [séc. IX], Cuenca; Zorita de los Canes; Molina de Aragón e Usagre [séc. XII]). Era utilizado, por sua velocidade, para caça de coelhos e lebres (o que ressalta na pintura de Bruegel seu caráter funesto: de caça de lebres a de um ser humano!). Há muitas representações imagéticas medievais de galgos em cenas de caça. Um belo registro é o da decoração mural (em têmpera e gesso) da Ermida (moçárabe) de San Baudelio en Casillas de Berlanga (Soria, séc. XII), em que há uma cena, Cacería de liebres (c. 1125, 183 x $355 \mathrm{~cm}$ ), em exposição no Museo del Prado (Sala 051C). Ver WALKER-MEIKLE, Kathleen. Medieval dogs. British Library, 2013.

${ }^{55}$ Agradeço à sugestão interpretativa da variedade de cruzes no quadro por parte do Prof. Dr. Luiz Augusto de Oliveira Astorga (Instituto Angelicum).

Quanto ao conceito de Christianitas - ideia de uma sociedade jurídico-espiritual de todos os cristãos, muito mais do que um simples conglomerado de reinos e povos cristãos, pois estes estariam unidos pela submissão espiritual à Igreja Romana, gerada a partir do pontificado de Gregório VII (1187) até Bonifácio VIII - ver OLIVER, Antonio. "Ecclesia y Christianitas en Inocencio III". In: Estudios Lulianos. Revista cuatrimestral de Investigación Luliana y Medievalística (EL). Palma de Mallorca: Maioricensis Schola Lullística, Instituto Internacional del Consejo Superior de Investigaciones Cientificas, vol. I, 1957, p. 217-244 e PACAUT, Marcel. "A Europa pontificia ou o tempo da cristandade (Meados do século XII - Final do século XIII)". In: LIVET, GEORGES e MOUSNIER, ROLAND MOUSNIER (dir.). História Geral da Europa I. Lisboa, Publicações Europa-América, 1996, p. 441-567.

Essa justa ordenação da desigualdade e da diversidade e sua orientação à Deus, isto é, a tranquilidade na ordem era uma das características filosóficas da Republica Christiana, situação prevista por Agostinho e esboçada em sua Cidade de Deus. Ver SAN AGUSTÍn. Obras de San Agustín. Tomo XVII. Madrid: BAC, 1958, p. 1362 (Civitate Dei, XIX, I).

${ }^{56}$ Sobre a história das doenças (e da Medicina) na Idade Média, indico os trabalhos de Maria Conforti (1961-) contidos nos quatro volumes de ECO, Umberto (org.). Idade Média. Lisboa: Publicações Dom Quixote, 2014-2015: Bárbaros, cristãos e muçulmanos (vol. I), Catedrais, cavaleiros e cidades (vol. II), Castelos, mercadores e poetas (vol. III) e Explorações, comércio e utopias (vol. IV). Trata-se da única autora escolhida pelo organizador para tratar da Medicina na Idade Média!

E também SOUSA, Jorge Prata de, COSTA, Ricardo da. "Corpo \& alma, vida \& morte na medicina ibérica medieval. O Regimento proveitoso contra a pestilência (c. 1496)". In: História, Ciência, Saúde - Manguinhos. Rio de Janeiro: Casa de Oswaldo Cruz/Fundação Oswaldo Cruz, set.-dez. 2005, volume XII, número 3, p. 841-851; ANGOTTI NETO, Hélio, COSTA, Ricardo da. "A lepra medieval e a Medicina metafórica de Ramon Llull (1232-1316)". In: ANGOTTI NETO, Hélio (org.). Mirabilia Medicince 5(2015/2), p. 1-30; COSTA, Ricardo da, e SILVA, Matheus Corassa da. "O Regimen sanitatis (1308) de Arnau de Vilanova (c.1238-1311) e sua prescrição da boa dieta". In: eHumanista 34 (2016). Journal of Iberian Studies, p. 463-480, e CORTIJO, Antonio; MARTINES, Vicent, e SANTOS, Armando Alexandre (orgs.). Mirabilia Journal 30 (2020/1) - War and Disease in Antiquity and the Middle Ages.

${ }^{57} \mathbf{J r} 2,15 ; 2,21 ; 4,7 ; 7,34 ; 12,10 ; 12,11 ; 25,9 ; 25,18 ; 25,38 ; 27,17 ; 32,43 ; 33,10 ; 44,2 ; 44,6 ; 44$, $22 ; 46,19 ; 48,9 ; 49,13 ; 49,17 ; 51,29 ; 51,43 ; 51,62$.

${ }^{58}$ Ez 5,$14 ; 6,14 ; 7,27 ; 12,20 ; 14,15 ; 15,8 ; 29,9 ; 29,10 ; 29,12 ; 30,7 ; 32,15 ; 33,28 ; 33,29 ; 35,3 ; 35$, $4 ; 35,7 ; 35,9 ; 35,14 ; 37,1-13$ (sobre o vale de ossos). 
59 “Assim também a ressurreição dentre os mortos. Semeia-se o corpo em corrupção; ressuscitará em incorrupção. Semeia-se em ignomínia, ressuscitará em glória. Semeia-se em fraqueza, ressuscitará com vigor. Semeia-se corpo natural, ressuscitará corpo espiritual. Se há corpo natural, há também corpo espiritual" (1Cor 15, 42-44).

${ }^{60}$ SPIERENBURG, Pieter. The Spectacle of Suffering: Executions and the Evolution of Repression: from a Preindustrial Metropolis to the European Experience. Cambridge University Press, 1984.

${ }^{61}$ Ver FRIEDLAND, Paul. Seeing Justice Done: The Age of Spectacular Capital Punishment in France. Oxford University Press, 2014.

${ }^{62}$ De modo geral, na Europa medieval, na ausência de um carrasco, as justiças eram obrigadas a recrutar açougueiros ou matadores, aos quais era permitido esconder o rosto com uma máscara para não serem conhecidos. A ausência de um carrasco profissional (especialmente na França) era indultado o criminoso que se oferecesse a executar os outros condenados. Uma das primeiras menções oficiais a um carrasco é a da Lei municipal de Augsburgo (1276). Na Catalunha medieval, o cargo foi definido no séc. XV: João II de Castela (1405-1454) estabeleceu-o de forma fixa nos tribunais de 1435; uma portaria (1525) de Carlos V (1500-1558) e outra (1556) de Felipe II (1527-1598) regulamentaram as atribuições dos carrascos e seu botim nas roupas e joias do executado. Nos séculos XV-XVII, a dificuldade de encontrar quem quisesse exercer essa profissão levou os filhos dos algozes a seguir a profissão de seus pais. Ver "Botxí". In: Gran Enciclopèdia Catalana.

Para a imagem do verdugo, ver GONZAGA, João Bernardino. A Inquisição em seu mundo. São Paulo: Saraiva, 1993; HARRINGTON, Joel F. The Faithful Executioner: Life and Death, Honor and Shame in the Turbulent Sixteenth Century. New York: Farrar, Straus and Giroux, 2013; BECHERBONNIER, Bernard. Carrascos de Paris: a Dinastia dos Sanson. São Paulo: Editora Mercuryo, 1991.

${ }^{63}$ Como, por exemplo, Maomé no Inferno do afresco O Juízo Final (1410) de Giovanni da Módena (c. 1409-1455). Ver COSTA, Ricardo da. "Maomé foi um enganador que fez um livro chamado Alcorão - A imagem do Profeta na filosofia de Ramon Llull (1232-1316)". In: Revista NOTANDUM, n. 27, Ano XIV, set-dez 2011, p. 19-35, Editora Mandruvá - Univ. do Porto.

${ }^{64}$ Mt 11, 15; 13, 9; 13, 43; Mc 4, 9; 7, 16; 4, 23; Lc 8, 8; Ap 2, 7; 2, 11; 2, 17; 2, 29; 3, 6; 3, 22; 13, 9.

${ }^{65}$ As questões teológicas mais diretamente vinculadas à audição (e sua importância na tradição cristã) são abordadas por HOLMES, Stephen R. Listening to the Past. The place of Tradition in Theology: on the Theory and Practice of Historical Theology. Paternoster Press, 2002. Para seus aspectos históricos, HARRISON, Carol. The Art of Listening in the Early Church. Oxford University Press, 2013.

"A Bíblia é uma das fontes da Revelação Divina aos homens, mas não é a única fonte. São duas, conforme ensina a Doutrina Católica, as fontes da Revelação: a Sagrada Escritura e a Tradição. A Tradição, que costuma ser grafada com inicial maiúscula, é constituída pelas "tradições não escritas, as quais, como que transmitidas de mão em mão, chegaram até nós desde os apóstolos, que a receberam ou dos lábios do próprio Jesus Cristo, ou por inspiração do Espírito Santo" (Concílio de Trento, sessão IV, de 8 de abril de 1546). A Tradição foi transmitida ininterruptamente desde a fundação da Igreja; é por ela que chega até nossos dias o ensinamento oral dos Apóstolos, e é por meio dela que os católicos podem conhecer a interpretação autêntica das Escrituras. A Tradição chegou até nós primeiramente através dos Apóstolos e discípulos do Senhor; em seguida, pelos chamados Padres da Igreja, ou seja, os grandes autores eclesiásticos dos primeiros séculos da Era Cristã; mais tarde, pelo ensinamento dos Santos e Doutores, fiéis continuadores da Tradição apostólica, sempre sob a autoridade e a vigilância dos Papas, sucessores de São Pedro e Vigários de Jesus Cristo na Terra." - SANTOS, Armando Alexandre dos. $\underline{O}$ vício capital da inveja, leitmotiv e fio condutor de "Curial e Guelfa". Análise da tradução ao português e estudo cultural e sintático-semântico. Alicante, tesis doctoral, noviembre de 2018, p. 43 (nota 49).

${ }^{66} \mathrm{Ecl} \mathrm{10,2.}$

${ }^{67}$ Mt 25, 33.

${ }_{68}^{68}$ Mt 25, 41 .

${ }^{69}$ SCRUTON, Roger. Understanding Music. Philosophy and Interpretation, op. cit., p. 43 (cap. Movement).

${ }^{70}$ Para a antropologia do ruído que opõe o som e seu sentido originário, sacrificial, ver WISNIK, José Miguel. O som e o sentido. Uma outra história das músicas. São Paulo: Companhia das Letras, 1989, p. 32-58.

${ }^{71}$ SCRUTON, Roger. Arte e Imaginação. Um estudo em filosofia da mente. São Paulo: É Realizações, 2017, p. 161. 
${ }^{72}$ Agradeço a leitura crítica feita pelos profs. drs. Antonio Celso Ribeiro (UFES), Armando Alexandre dos Santos (Instituto Histórico e Geográfico de São Paulo) e Luiz Augusto de Oliveira Astorga (Instituto Angelicum). 